\title{
Towards understanding factors that govern fertilizer response in cassava: lessons from East Africa
}

\author{
Anneke M. Fermont - Pablo A. Tittonell • \\ Yona Baguma · Pheneas Ntawuruhunga · \\ Ken E. Giller
}

Received: 25 September 2008/Accepted: 30 March 2009/Published online: 29 April 2009

(C) The Author(s) 2009. This article is published with open access at Springerlink.com

\begin{abstract}
Information on fertilizer response in cassava in Africa is scarce. We conducted a series of onfarm and on-station trials in two consecutive years to quantify yield responses of cassava to mineral fertilizer in Kenya and Uganda and to evaluate factors governing the responses. Average unfertilized yields ranged from 4.2 to $25.7 \mathrm{t} \mathrm{ha}^{-1}$ between sites and years. Mineral fertilizer use increased yields significantly, but response to fertilizer was highly variable $(-0.2$ to $\left.15.3 \mathrm{t} \mathrm{ha}^{-1}\right)$. Average yield response per $\mathrm{kg}$ applied nutrient was 37, 168 and 45 and 106, 482 and $128 \mathrm{~kg}$ fresh yield per $\mathrm{kg}$ of applied $\mathrm{N}, \mathrm{P}$ and $\mathrm{K}$, respectively in
\end{abstract}

A. M. Fermont $(\bowtie) \cdot$ P. Ntawuruhunga International Institute of Tropical Agriculture (IITA), P.O. Box 7878, Kampala, Uganda

e-mail: a.fermont@cgiar.org

A. M. Fermont · P. A. Tittonell · K. E. Giller Plant Production Systems, Department of Plant Sciences, Wageningen University, P.O. Box 430, 6700 AK

Wageningen, The Netherlands

P. A. Tittonell

Centre de Cooperation International en Recherche Agronomique pour le Développement, Persyst-URSCA, TA B 102/02 Avenue Agropolis, 34398 Montpellier Cedex 5, France

Y. Baguma

National Crops Resources Research Institute (NaCRRI), P.O. Box 7084, Kampala, Uganda
2004 and 2005. Fertilizer response was governed by soil fertility, rainfall and weed management, but was not influenced by variety, pest and disease pressure and harvest age. Relative $\mathrm{N}$ and $\mathrm{K}$ yields were positively correlated to SOC and exchangeable $\mathrm{K}$, while response to fertilizer decreased on more fertile soils. Still, fertilizer response varied widely on low fertility soils (e.g. on soils with $<10 \mathrm{~g} \mathrm{~kg}^{-1} \mathrm{SOC}$, responses ranged from -8.6 to $24.4 \mathrm{t} \mathrm{ha}^{-1}$ ), indicating strong interactions between factors governing fertilizer response. Response to fertilizer was reduced if total rainfall $<1,500 \mathrm{~mm}$ or rainfall from 0 to 3 months after planting $<400 \mathrm{~mm}$. Fertilizer application promoted plant growth and resulted in a better soil coverage and reduced weed competition. Yields in fertilized fields were independent of weed management, unless growing conditions were unfavourable.

Keywords Cost-benefit analysis - Kenya - Rainfall · Small-holder farms $\cdot$ Soil fertility $\cdot$ Sub-Saharan Africa $\cdot$ Uganda $\cdot$ Variability $\cdot$ Weed management

\section{Introduction}

In Asia and Latin-America, mineral fertilizer use is a standard agronomic practice for farmers to increase the productivity and profitability of cassava production. In Africa, smallholder farmers use little or no fertilizer at all (an average of $9 \mathrm{~kg} \mathrm{ha}^{-1}$ year $^{-1}$, compared with 73 and $135 \mathrm{~kg} \mathrm{ha}^{-1}$ year $^{-1}$ used in 
Latin-America and Asia, respectively; Kelly 2006). They rarely use any fertilizer on cassava (Nweke 1994), as there appears to be a common belief that cassava does not need fertilizer. This seems to be based on the ability of cassava to yield in areas with such low soil fertility that other crops fail.

Due to increasing population pressure, coupled with a lack of land, farming systems in large parts of Africa are intensifying. Traditional management practices (e.g. fallow, manure use) to maintain soil fertility often are no longer feasible. When farming systems in parts of East Africa intensified to such extent that natural fallowing no longer was an option, farmers expanded the acreage under cassava which is increasingly grown on poor fertility soils, as they consider cassava a crop that restores soil fertility (Fermont et al. 2008; Ebanyat, unpublished). However, to maintain productivity in these systems, the use of external inputs seems inevitable in the near future. At the same time, the growing demands for cassava in the food, fodder and industrial (starch, biofuel) markets, also increases the likelihood that farmers will adopt fertilizer to improve cassava productivity in their farms in order to profit from these developments.

The Africa Fertilizer Summit held in Nigeria in 2006 and the Soil health Initiative of the Alliance for a Green Revolution in Africa (AGRA) launched in 2007 show that there is an increasing consensus that mineral fertilizers are essential in Africa to counteract declining soil fertility and improve agricultural productivity. Although cassava produces reasonable yields on infertile soils, there is no doubt that fertilizer can increase cassava yields. Cassava is a heavy potassium feeder, but also requires nitrogen, phosphorus and meso-/micro-nutrients to produce good yields (Howeler 2008, 2002; Nguyen et al. 2002). Nonetheless, experience with fertilizer use on cassava in Africa is extremely limited and results are elusive. Some (Richards 1979; Arene and Odurukwe 1976) reported yield increases due to fertilizer use, others (Lema et al. 2004; Ogbe et al. 1993) observed no effect of fertilizer use, while Ofori (1973) even found a negative effect of fertilizer use on a forest soil in Ghana. Carsky and Toukourou (2005) observed an increasing response to fertilizer over time in farmers' fields in Benin. Soils in Africa are highly heterogeneous, which has strong effects on crop response to fertilizer, due to differences in soil type, historical management and resource allocation (Zingore et al. 2007) or soil fertility status (Vanlauwe et al. 2006). We hypothesize that heterogeneity in soils within farms and between farms and research stations is partly the cause of the reported range in cassava yield responses to fertilizer.

To investigate this hypothesis, a series of on-farm and on-station trials were conducted during two consecutive years across the mid altitude zone of western Kenya and Uganda, where cassava is an important food and cash crop. Average cassava yields were 9.1 and $14.4 \mathrm{t} \mathrm{ha}^{-1}$ in 2005 in Kenya and Uganda, respectively (FAO 2008). Environments in this region are highly heterogeneous, covering a wide range in agro ecological conditions. Our specific objectives were (1) to quantify the response of cassava to mineral $\mathrm{N}, \mathrm{P}$ and $\mathrm{K}$ fertilizers in smallholder farmer conditions and (2) to evaluate the role of management, abiotic and biotic factors in governing such responses.

\section{Materials and methods}

Selection of study sites

Experiments were conducted in six on-farm and two on-station locations in western Kenya and central/ eastern Uganda, which were chosen to represent the variation in environments and cassava-based cropping systems found in the mid-altitude zone of eastern Africa. In western Kenya these included the sub-locations of Kwang'amor $\left(0^{\circ} 29^{\prime} \mathrm{N}, 34^{\circ} 14^{\prime} \mathrm{E}\right)$, Mungatsi $\left(0^{\circ} 27^{\prime} \mathrm{N} ; 34^{\circ} 18^{\prime} \mathrm{E}\right)$, Nambale $\left(0^{\circ} 28^{\prime} \mathrm{N}\right.$, $\left.34^{\circ} 14^{\prime} \mathrm{E}\right)$ and Ugunja $\left(0^{\circ} 10^{\prime} \mathrm{N} ; 34^{\circ} 18^{\prime} \mathrm{E}\right)$ in Teso, Busia, Busia and Siaya districts, respectively, and the research farm of the Kenyan Agricultural Research Organisation (KARI) in Alupe, Busia district $\left(0^{\circ} 30^{\prime} \mathrm{N}, 34^{\circ} 08^{\prime} \mathrm{E}\right)$. In Uganda the study sites were located in the parishes of Kisiro $\left(0^{\circ} 67^{\prime} \mathrm{N} ; 33^{\circ} 80^{\prime} \mathrm{E}\right)$ and Minani $\left(0^{\circ} 80^{\prime} \mathrm{N} ; 33^{\circ} 57^{\prime} \mathrm{E}\right)$ in Iganga district and on the research farm of the National Crops Resources Research Institute (NaCRRI) $\left(0^{\circ} 32^{\prime} \mathrm{N}, 32^{\circ} 37^{\prime} \mathrm{E}\right)$ in Namulonge, Wakiso district. Altitude ranged between 1,100 and 1,260 masl. Main soils in the region include ferric and orthic Acrisols and orthic and haplic Ferralsols, which have developed from strongly weathered granite or sedimentary parent material (KARI 2000; Jaetzold and Schmidt 1982). 
The climate in all sites is sub-humid with a bimodal rainfall distribution, such that the production of most annual crops takes place twice a year, during the long (March to June) and the short rains (September to November). Cassava is normally planted in the first 2 months of either the short or long rains and remains in the fields for about a year, thus receiving two peaks of rainfall during its growth cycle.

On-farm and on-station trials

Two sets of experiments were conducted to quantify the response of cassava to mineral $\mathrm{N}, \mathrm{P}$ and $\mathrm{K}$ fertilizers and to identify the main factors that govern such responses (Table 1). The first set of trials, planted in 2004 and harvested in 2005, was set up to study the response of three selected cassava varieties to NPK fertilizer. This set is labelled '2004 trials' throughout the paper. The second set of trials, planted in 2005 and harvested in 2006, focused on the response of cassava to individual applied nutrients and consisted of the best performing varieties in the 2004 trials with five fertilizer rates. This set is labelled '2005 trials' throughout the paper.

The 2004 trials consisted of a total of 49 on-farm trials and three on-station trials in Kenya and Uganda. In the on-station trials a randomized complete block design (RCBD) with four replicates was used, while in the on-farms a criss-cross design (Mead 1988) was used to facilitate farmer evaluation, whereby each row was randomly assigned to a fertilizer rate and each column was planted with one variety. Between six and ten farmers participated in each site and each farmer was considered a single block repetition. In Kenya, cassava varieties MM96/5280, MM95/4884 and TMS 30572 (released officially in Uganda as Nase 3) were planted, while in Uganda TMSI92/ 0067, TMSI92/0057 and Nase 3 were planted. Nase 3 is the most widely adopted improved variety in Uganda and Kenya (Legg et al. 2006). The other varieties were chosen due to good performance in onfarm selection trials. Fertilizer rates were (T0) no fertilizer added; and (T1) 100:22:83 N:P:K (i.e. 100:50:100 kg ha $\left.{ }^{-1} \mathrm{~N}: \mathrm{P}_{2} \mathrm{O}_{5}: \mathrm{K}_{2} \mathrm{O}\right)$. $\mathrm{N}$ fertilization was divided in three split applications: $18 \mathrm{~kg} \mathrm{~N}^{-1}$ at planting as diammonium phosphate and $41 \mathrm{~kg} \mathrm{~N} \mathrm{ha}^{-1}$ at 1 and 3 months after planting (MAP) as urea. All $\mathrm{P}$ fertilizer was applied in the planting hole as diammonium phosphate, while $\mathrm{K}$ fertilizer was divided in two equal splits: $41.5 \mathrm{~kg} \mathrm{~K} \mathrm{ha}^{-1}$ at $1 \mathrm{MAP}$ and at $3 \mathrm{MAP}$ as potassium sulphate. Top dressings were broadcast after weeding, before expected rainfall. The variety TMSI92/0057 succumbed to cassava brown streak disease, a new viral disease in the area, and results are not included.

Table 1 Overview of cassava fertilizer trials in Kenya and Uganda

\begin{tabular}{|c|c|c|c|c|c|c|c|}
\hline Year & Country & Sites & \# Trials & Planting date & Harvesting date & Varieties & $\begin{array}{l}\text { Fertilizer } \\
\text { treatment }^{\mathrm{a}}\end{array}$ \\
\hline \multirow[t]{5}{*}{2004} & Kenya & On-station A: KARI & 1 & $20 / 4 / 04$ & $27 / 07 / 05$ & Nase 3, & T0 and \\
\hline & & On-station B: KARI & 1 & $1 / 07 / 04$ & $31 / 08 / 05$ & MM96/5280 & $\mathrm{T} 1$ \\
\hline & & $\begin{array}{l}\text { On-farm: Kwang'amor, Mungatsi, } \\
\text { Nambale and Ugunja }\end{array}$ & 35 & $1-7 / 4 / 04$ & $9-12 / 03 / 05$ & and MM96/4884 & \\
\hline & Uganda & On-station: NaCRRI & 1 & $26 / 03 / 04$ & $6 / 04 / 05$ & Nase 3 , & T0 and \\
\hline & & On-farm: Minani and Kisiro & 14 & $15-16 / 9 / 04$ & $12-13 / 10 / 05$ & $\begin{array}{l}\text { TMSI92/0067 } \\
\text { and TMSI92/0057 }\end{array}$ & $\mathrm{T} 1$ \\
\hline \multirow[t]{4}{*}{2005} & Kenya & On-station: KARI & 1 & $22 / 04 / 05$ & $18 / 05 / 06$ & MM96/5280 & $\mathrm{T} 0, \mathrm{~T} 1, \mathrm{~T} 2$ \\
\hline & & $\begin{array}{l}\text { On-farm: Kwang'amor, Mungatsi, } \\
\text { Nambale and Ugunja }\end{array}$ & 34 & $1-8 / 04 / 05$ & $2-5 / 05 / 06$ & & T3 and T4 \\
\hline & Uganda & On-station: NaCRRI & 1 & $25 / 04 / 05$ & $26 / 06 / 05$ & TMSI92/0067 & $\mathrm{T} 0, \mathrm{~T} 1, \mathrm{~T} 2$, \\
\hline & & On-farm: Minani and Kisiro & 16 & $6-8 / 9 / 05$ & $11-14 / 09 / 05$ & & $\mathrm{~T} 3$ and T4 \\
\hline
\end{tabular}

${ }^{\mathrm{a}} \mathrm{T} 0=0: 0: 0 ; \mathrm{T} 1=100: 22: 83 ; \mathrm{T} 2=0: 22: 83 ; \mathrm{T} 3=100: 0: 83 ; \mathrm{T} 4=100: 22: 0 \mathrm{~kg} \mathrm{ha}^{-1} \mathrm{~N}: \mathrm{P}: \mathrm{K}$ 
The 2005 trials consisted of a total of 50 on-farm trials and 2 on-station trials in Kenya and Uganda, all located in different fields than the 2004 trials. A complete randomized block design was used in all trials. In Kenya cassava variety MM96/5280 was used, while in Uganda TMSI92/0067 was used. Fertilizer rates were: (T0) no fertilizer added; (T1) 100:22:83 $\mathrm{kg} \mathrm{ha}^{-1} \mathrm{~N}: \mathrm{P}: \mathrm{K}$; (T2) as T1 but no N, (T3) as $\mathrm{T} 1$ but no P, (T4) as T1 but no K. Fertilizer application was similar to the 2004 trials, except in $\mathrm{T} 3$ where all $\mathrm{N}$ was given as urea and in $\mathrm{T} 2$ where $\mathrm{P}$ was applied as triple superphosphate. Top dressings were applied, after weeding, in a hole on one side of the plant and covered with soil.

In both sets of trials, each plot was $8 \times 7 \mathrm{~m}$ with a net harvest area of $5 \times 4 \mathrm{~m}$. Field selection and land preparation in the on-farm trials was done by farmers, either by hoe, oxen or tractor, depending on local practices, and experiments were planted by farmers and researchers together. The recommended planting distance of $1 \times 1 \mathrm{~m}$ was used. Fresh cuttings of $20-25 \mathrm{~cm}$ were placed horizontally in a $10-20 \mathrm{~cm}$ deep planting hole and covered with soil. Weeding was done in the on-farm trials by farmers, according to their own judgement, while on-station trials were kept weed-free. Crops were harvested between 11.5 and 13 MAP by farmers and researchers together in the on-farm trials and between 12 and 15 MAP in the on-station trials.

Measurements and chemical analysis

At harvest, all plants in the net harvest area of each plot were counted and uprooted. If less than $80 \%$ (e.g. 16 plants) were present, additional representative plants from non-border rows were included to make a total of 16 plants (R. Howeler, pers. comm. 2004). Plants were split into above-ground biomass (stems and leaves), marketable and non-marketable storage roots. Storage roots were considered non-marketable if farmers considered them too small for peeling (i.e. diameter smaller than $\pm 3 \mathrm{~cm}$ ). Total fresh weight of each component was taken and used to calculate fresh cassava yield $\left(\mathrm{t} \mathrm{ha}^{-1}\right)$ and fresh aboveground biomass $\left(\mathrm{t} \mathrm{ha}^{-1}\right)$ at the time of harvest. The apparent fresh HI at harvest was calculated, excluding the weight of leaves fallen during the growing period. A sub-sample of approximately $0.2 \mathrm{~kg}$ was taken from the top, middle and bottom end of five representative marketable storage roots to determine the dry matter content of the marketable storage roots from each plot after chopping, air-drying and subsequent ovendrying at $70^{\circ} \mathrm{C}$, to constant weight. The relative fresh cassava yield in absence of $\mathrm{N}\left(\mathrm{RY} \mathrm{Y}_{\mathrm{N}}\right), \mathrm{P}\left(\mathrm{RY} \mathrm{Y}_{\mathrm{P}}\right)$ or $\mathrm{K}$ $\left(R Y_{K}\right)$ was calculated in relation to the NPK fertilizer treatment (T1) as

$\mathrm{RY}_{x}=\frac{\text { Fresh yield in treatment without } x}{\text { Fresh yield in NPK treatment }}$

where $x$ stands for $\mathrm{N}, \mathrm{P}$ or $\mathrm{K}$. The $\mathrm{RY}_{x}$ approaches 1 when the response to applied nutrient $X$ becomes 0 .

Top soil samples $(0-20 \mathrm{~cm})$ were taken with an auger from five locations in the unfertilized plots of each field, and a composite air-dried soil sample of $1.5 \mathrm{~kg}$ per plot was sent to the laboratory, where they were oven-dried, passed through a $2 \mathrm{~mm}$ sieve and analysed for $\mathrm{pH}$, available $\mathrm{P}$, exchangeable $\mathrm{K}, \mathrm{Ca}$, $\mathrm{Mg}$, total $\mathrm{N}$, soil organic carbon and texture according to Okalebo et al. (2002). Daily rainfall data for the research stations were obtained from KARI and NaCRRI. For the on-farm sites, daily rainfall data were collected by one farmer per site by means of a simple rainfall gauge. Total rainfall during the growth cycle, rainfall from 0-3, 3-6, 6-9, 9-12, 12-15 MAP and the total number of rain days during the growth cycle were included in further analysis. Field technicians, who regularly visited the fields, scored overall weed management (WM) by farmers during the growing period on a scale from 1 (very poor) to 5 (very good).

\section{Scoring pests and diseases}

The most important cassava pests and diseases in East Africa include cassava mosaic disease, bacterial blight, green mites, anthracnose disease and mealy bugs (Legg et al. 2006; IITA 1990). Cassava brown streak disease was first observed as a new viral disease in Uganda in 2004 (Alicai et al. 2007). Except for the Ugandan on-farm trials in 2004, the 20 plants in the harvest area of each plot were scored for incidence (yes/no) and severity on a scale of 1 to 5 (IITA 1990) at 3, 6 and 9 MAP for all mentioned pests and diseases. An average disease severity index (DSI) was calculated for each recording date and each pest/disease for all unfertilized (T0) and NPK fertilized (T1) plots according to the following formula adapted from (Kim et al. 2000): 


$$
\begin{aligned}
\mathrm{DSI}= & \left(\frac{\sum_{i} \text { severity score }-(\# \text { plants scored })}{4 \times \# \text { plants scored }}\right) \\
& \times 100
\end{aligned}
$$

The DSI ranges from 0 for a plot with all healthy plants (score 1) to 100 for a plot where all plants received a score 5. Adjusting the procedure of Zinsou et al. (2004) to capture disease progress during the growth cycle into one number, we then determined the area under disease severity index progress curve (AUSiPC) for each disease in each plot as:

$\mathrm{AUSiPC}=\sum_{i}\left(\frac{\mathrm{DSI}_{i}+\mathrm{DSI}_{i-1}}{2}\right) \times\left(t_{i}-t_{i-1}\right)$

whereby $\mathrm{DSI}_{i}$ is the disease severity index at time $t_{i}$ with $t$ corresponding to the number of months after planting. The AUSiPC ranges from 0 for a plot where all plants were healthy during the whole growth cycle to 750 for a plot where all plants received score five during the whole growth cycle.

The boundary line approach to analyse yield limitations

The boundary line approach (Shatar and McBratney 2004; van Asten et al. 2003; Webb 1972) was used to define boundary lines that represent the maximum (or limited) response of a dependent variable (e.g. yield) to an independent variable (e.g. rainfall) in a given environment. Boundary lines were fitted through boundary points that corresponded to the highest response of the dependent variable at each value of the independent variable, using the following model:

$y_{1}=\frac{y_{\max }}{(1+(K \times \operatorname{EXP}(-R \times x)))}$

whereby $y_{\max }$ is the observed maximum yield level, $x$ is the independent variable and $K$ and $R$ are constants. The best boundary line model was obtained by minimizing the root mean squared error (RMSE) between the fitted boundary line $\left(y_{1}\right)$ and the boundary points $\left(y_{\mathrm{p}}\right)$; i.e. the maximum yield values observed at each given value of the independent variable.

Partial gross margin analysis

Partial gross margins of NPK fertilizer use were calculated for the 2004 and 2005 trials. Marginal costs taken into account were fertilizer, transport and application costs of fertilizer. Average wholesale market prices in 2004 and 2005 were used for the full fertilizer package (378,200 Uganda Shillings; UgSh and 17,416 Kenya Shillings; KSh) with 1 US\$ = $1,818 \mathrm{UgSh}$ and $80 \mathrm{KSh}$. Transport costs for fertilizer were estimated at 1 US\$ per bag of $50 \mathrm{~kg}$. Labour costs for fertilizer application were assumed to be similar to those of cassava planting. Prices for hired labour were used to mirror the opportunity costs of labour (CIMMYT 1988) as farmers hired labour for agricultural activities in the study areas. Labour rates for cassava planting were obtained from a farm survey in three Ugandan and three Kenyan sites and did not vary between sites within a country. Average wholesale price for cassava chips in 2004 and 2005 (132\$ ton ${ }^{-1}$ for Uganda and $150 \$$ ton $^{-1}$ for Kenya; IITA, unpublished) were adjusted to a field price of $118 \$$ ton $^{-1}$ for Uganda and $134 \$$ ton $^{-1}$ for Kenya to account for harvest and post-harvest labour costs that are proportional to yield (CIMMYT 1988). Harvest and post-harvest labour costs expressed per ton of product harvested were measured in Uganda and took into account labour for harvesting, transport, peeling, chipping and drying and costs related to bagging and storage. Marginal revenue was calculated as marginal yields times the field price of cassava. The Value/ Cost Ratio (VCR) was calculated as the marginal revenue over the marginal costs. Under conditions of small-scale agriculture it is often considered that a VCR of two or more is an indication that a new production technology creates sufficient economic incentives for farmers to adopt it (Kelly 2006), although adoption may also depend on the absolute profit margin generated by the technology.

Statistical analysis

Analysis of variance was performed to test for the effect of site, season, fertilizer treatment and variety on the biophysical variables, cassava fresh yields, yield components, plant growth variables and partial gross margins. Non-parametric tests for two or more independent samples using the Mann-Whitney $U$ or Kruskal Wallis test, respectively, were employed if variables could not be normalised by transformation. A non-parametric test for two related samples (Wilcoxon) was used to test for the effect of fertilizer 
on pest and disease progression. The CROSSTAB procedure using Pearson Chi square analysis was used to test for significance of differences between years for the percentage of farmers having a VCR $>2$. Statistical analyses were carried out using Genstat for Windows (version 10.2) and SPSS for Windows (version 10.0).

\section{Results}

Variability in abiotic and biotic factors across sites and seasons

Total rainfall during the growing seasons of the 2004 and 2005 trials ranged from 1,065 $\mathrm{mm}$ for the 2004 trial at the NaCRRI station to 2,460 mm for the 2005 trials in Nambale (Fig. 1). The KARI station in Kenya received considerably less rain in 2004 and considerably more rain in 2005 than the long-term mean, while rainfall at the NaCRRI station in Uganda was around average in both years. In the Kenyan onfarm sites, the 2005 trials received more rainfall during early (2 and 4 MAP) and late (10-11 MAP) growth stages than the 2004 trials, while they were also harvested 5 weeks later. Consequently, the 2005 Kenyan trials received between 361 and $741 \mathrm{~mm}$ more rainfall than the 2004 trials. The opposite was true for the Ugandan on-farm sites. The 2004 trials received more rainfall during the first 4-6 MAP, resulting in $177-479 \mathrm{~mm}$ more total rainfall than the 2005 trials. Soil texture ranged from sandy loam to sandy clay loam to clay loam (Table 2). Soil fertility was generally low, although the soils on the experimental stations had inherently higher concentrations of SOC, total $\mathrm{N}, \mathrm{Ca}$ and $\mathrm{Mg}$ due to a higher clay content than the soils of farmer fields where trials were conducted $(P<0.001)$. Experimental sites used in 2004 had higher concentrations of total $\mathrm{N}$ and available $\mathrm{K}$ than sites used in $2005(P<0.05)$, while Kenyan soils had a lower concentration of all macro nutrients than Ugandan soils $(P<0.01)$ Average soil
Fig. 1 Rainfall measured in the study sites between March 2004 and September 2006 for the 2004 and 2005 trials in Kenya and Uganda. a Average monthly rainfall in Kenya; b Average monthly rainfall in Uganda; and c Total rainfall per site in 2004 and 2005. The arrows in (a) and (b) indicate the growing season (from planting to harvesting) of the on-station and on-farm trials
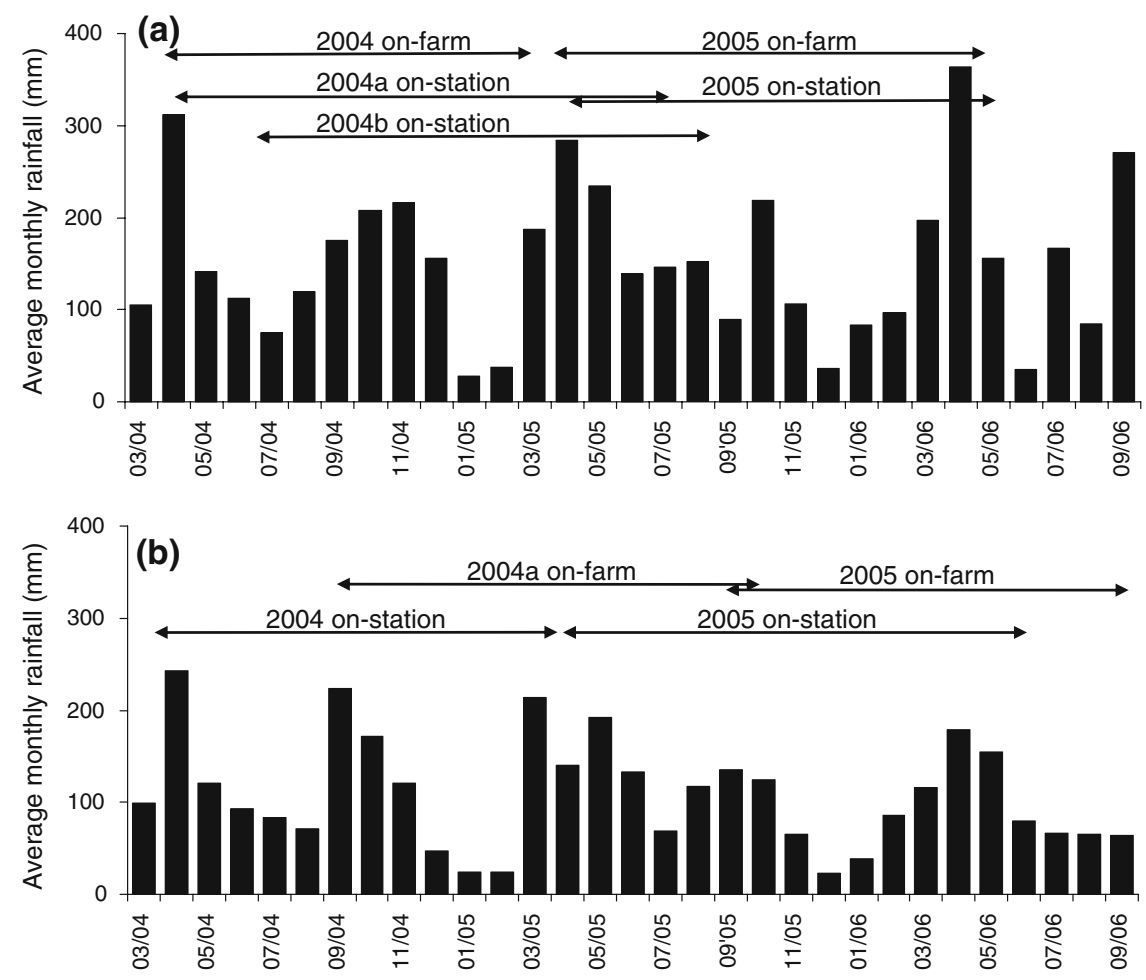

(c)

\begin{tabular}{|c|c|c|c|c|c|c|c|c|}
\hline & \multicolumn{5}{|c|}{ Kenya } & \multicolumn{3}{|c|}{ Uganda } \\
\hline & Kwang'amor & Mungatsi & Nambale & Ugunja & KARI & Kisiro & Minani & NaCRRI \\
\hline Total rainfall $(\mathrm{mm}) 2004$ & 1447 & 1781 & 1830 & 1316 & 2268 & 1478 & 1771 & 1065 \\
\hline Total rainfall $(\mathrm{mm}) 2005$ & 2187 & 2377 & 2460 & 1677 & 1914 & 1270 & 1292 & 1152 \\
\hline
\end{tabular}


Table 2 Main abiotic and biotic characteristics and weed management score of the 2004 and 2005 trials in eight sites in Kenya and Uganda

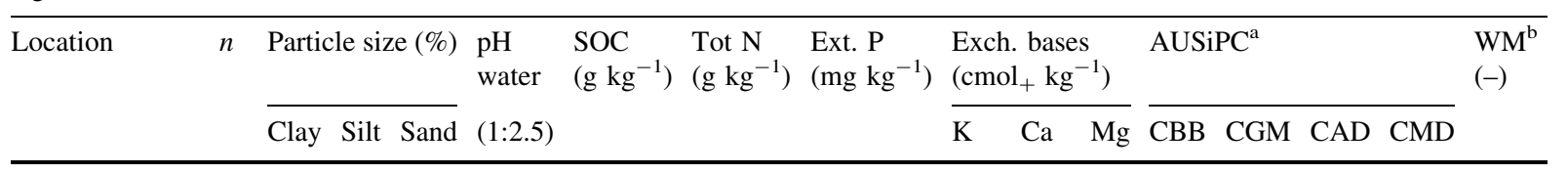

2004

Kenya

\begin{tabular}{|c|c|c|c|c|c|c|c|c|c|c|c|c|c|c|c|c|}
\hline Kwang'amor & 10 & 17 & 8 & 76 & 6.0 & 6.9 & 0.46 & 4.5 & 0.33 & 0.8 & 0.3 & 113 & 105 & 12 & 95 & 3.6 \\
\hline Mungatsi & 7 & 28 & 18 & 54 & 5.5 & 11.4 & 1.04 & 5.8 & 0.56 & 1.6 & 0.8 & 76 & 64 & 1 & 132 & 4.4 \\
\hline Nambale & 9 & 27 & 14 & 59 & 5.4 & 10.6 & 0.93 & 3.8 & 0.37 & 1.3 & 0.8 & 146 & 75 & 23 & 68 & 3.1 \\
\hline Ugunja & 9 & 29 & 21 & 50 & 5.7 & 8.7 & 0.76 & 3.0 & 0.40 & 0.8 & 0.7 & 70 & 41 & 6 & 86 & 3.4 \\
\hline KARI & 8 & 37 & 21 & 42 & 5.2 & 14.7 & 1.34 & 3.1 & 0.42 & 4.4 & 2.7 & 172 & 18 & 6 & 111 & 5 \\
\hline \multicolumn{17}{|l|}{ Uganda } \\
\hline Kisiro & 6 & 26 & 7 & 67 & 6.5 & 8.0 & 0.49 & 12.3 & 0.46 & 2.8 & 0.8 & & & & & 3.5 \\
\hline Minani & 8 & 16 & 9 & 76 & 6.2 & 10.0 & 0.99 & 5.6 & 0.78 & 6.5 & 1.7 & & & & & 3.2 \\
\hline NaCRRI & 4 & 35 & 11 & 54 & 6.2 & 20.5 & 2.08 & 7.1 & 1.32 & 11.4 & 5.1 & 58 & 71 & 1 & 199 & 5 \\
\hline $\mathrm{SED}^{\mathrm{c}}$ & & 2 & 3 & 3 & 0.2 & 1.0 & 0.24 & 1.7 & 0.19 & 0.9 & 0.3 & 18 & 15 & 7 & 34 & 0.3 \\
\hline
\end{tabular}

2005

Kenya

$\begin{array}{lrrrrrrrrrrrrrrr}\text { Kwang'amor } & 7 & 18 & 11 & 75 & 5.8 & 7.2 & 0.38 & 8.5 & 0.33 & 1.7 & 0.5 & 119 & 126 & 10 & 2.9 \\ \text { Mungatsi } & 8 & 26 & 19 & 55 & 5.4 & 9.0 & 0.48 & 5.3 & 0.33 & 0.5 & 0.2 & 144 & 123 & 29 & 3.6 \\ \text { Nambale } & 9 & 28 & 15 & 57 & 5.3 & 8.7 & 0.50 & 3.4 & 0.19 & 0.8 & 0.4 & 140 & 119 & 2 & 3.2 \\ \text { Ugunja } & 10 & 32 & 23 & 44 & 5.7 & 7.8 & 0.45 & 2.7 & 0.22 & 0.9 & 0.4 & 125 & 31 & 1 & 3.6 \\ \text { KARI } & 4 & 40 & 19 & 41 & 5.1 & 17.1 & 1.52 & 2.3 & 0.35 & 4.9 & 3.4 & 197 & 46 & 14 & 5 \\ \text { Uganda } & & & & & & & & & & & & & & & \\ \text { Kisiro } & 8 & 14 & 9 & 67 & 6.3 & 8.5 & 0.88 & 4.6 & 0.32 & 3.4 & 1.5 & 51 & 3 & 0 & 3.5 \\ \text { Minani } & 8 & 19 & 8 & 74 & 6.1 & 9.4 & 1.0 & 2.5 & 0.55 & 3.6 & 1.4 & 53 & 38 & 0 & 3.4 \\ \text { NaCRRI } & 4 & 39 & 10 & 51 & 6.4 & 18.9 & 1.8 & 5.7 & 0.97 & 8.4 & 3.0 & 120 & 33 & 0 & 5 \\ \text { SED } & & 8 & 2 & 5 & 0.1 & 1.2 & 1.00 & 1.3 & 0.12 & 0.8 & 0.3 & 11 & 17 & 7 & 0.5\end{array}$

${ }^{a}$ Average area under severity index progress curve (AUSiPC - see Materials and Methods) for $C B B$ cassava bacterial blight, $C G M$ cassava green mites, $C A D$ cassava antracnose disease and $C M D$ cassava mosaic disease. Scores for CMD are for MM96/4884 and Nase 3 only as MM96/5280 and TMSI92/0067 are resistant to CMD

b $W M$ weed management ranges from one (very poor) to five (good)

c SED standard error of the differences

organic carbon values ranged from 6.9 to $20.5 \mathrm{~g}$ $\mathrm{kg}^{-1}$, while average available $\mathrm{P}$ and exchangeable $\mathrm{K}$ ranged from 2.3 to $12.3 \mathrm{mg} \mathrm{kg}^{-1}$ and 0.19 to $1.32 \mathrm{cmol}_{(+)} \mathrm{kg}^{-1}$, respectively.

Bacterial blight and green mite symptoms were observed on all varieties and in all trials and usually increased with plant age. Bacterial blight infections and green mite infestations were more severe in Kenya than in Uganda $(P<0.001)$ and bacterial blight was overall more important in 2005 than in $2004(P<0.01)$, although the most severe infections were noted in Nambale in $2004 / 5$ with $37 \%$ of the monitored plants having a severity score of 4-5 ('candle stick' stage) at 9 MAP, compared with less than $5 \%$ in all other sites. Moderate green mite infestations were observed in Nambale, Mungatsi and Kwang'amor with $20-30 \%$ of the monitored plants having a severity score of 3-4 at 6 MAP. Cassava mosaic disease was observed on varieties that are not resistant to the virus (Nase 3 and MM96/4884), anthracnose symptoms were found only in individual fields in Kenya that were hit by severe hail storms, while mealy bugs were not observed in any of the sites. 
Effect of fertilizer on cassava yields and yield components

In Kenya, average fresh yields of unfertilized cassava ranged from 4.2 to $16.3 \mathrm{t} \mathrm{ha}^{-1}$ in the 2004 trials and from 9.7 to $18.7 \mathrm{t} \mathrm{ha}^{-1}$ in the 2005 trials and were significantly $(P<0.001)$ higher in the latter set of trials (Table 3). In Uganda, yields of unfertilized cassava also tended to be higher in the 2005 trials (14.4-25.7 $\mathrm{t} \mathrm{ha}^{-1}$ ) than in the 2004 trials (11.919.1 $\left.\mathrm{t} \mathrm{ha}^{-1}\right)$. NPK fertilizer application (100:22:83 $\mathrm{N}: \mathrm{P}: \mathrm{K})$ increased cassava yields in both countries and both years $(P<0.01)$. Yield responses were much stronger in the 2005 than in the 2004 trials $(P<0.001)$. In Kenya, average yield responses in the 2004 trials ranged from 0.9 to $5.6 \mathrm{t} \mathrm{ha}^{-1}$ and from 6.0 to $15.3 \mathrm{t} \mathrm{ha}^{-1}$ in the 2005 trials (Table 3). In Uganda,

Table 3 Fresh cassava yields $\left(\mathrm{t} \mathrm{ha}^{-1}\right)$ of selected varieties with selected NPK fertilizer treatments $\left(\mathrm{N}\right.$ : $100 \mathrm{~kg} \mathrm{ha}^{-1}$; P: $22 \mathrm{~kg} \mathrm{~h}^{-1}$; $\mathrm{K}: 83 \mathrm{~kg} \mathrm{ha}^{-1}$; '-' signifies no fertilizer) in the yield responses in the 2004 trials ranged from -0.2 to $7.7 \mathrm{t} \mathrm{ha}^{-1}$ and from 0.5 to $12.9 \mathrm{t} \mathrm{ha}^{-1}$ in the 2005 trials. The average yield response per $\mathrm{kg}$ applied nutrient was 37, 168 and $45 \mathrm{~kg}$ fresh yield per $\mathrm{kg}$ of applied N, P and K, respectively, in 2004 and 106, 482 and $128 \mathrm{~kg}$ fresh yield per $\mathrm{kg}$ of applied $\mathrm{N}, \mathrm{P}$ and $\mathrm{K}$, respectively, in 2005. In both countries, yields varied between varieties $(P<0.01)$ and between environments $(P<0.01)$, but yield responses to fertilizer (i.e. the relative increase with respect to control) did not differ between varieties and environments nor did fertilized yields of the 2005 trials differ between sites.

The missing nutrient trials showed significant yield responses to applied $\mathrm{N}$ and $\mathrm{P}$ in all on-farm sites $(P<0.05$; Fig. 2$)$. Yield responses to applied $\mathrm{K}$ were significant in most Kenyan on-farm sites, but not in the Ugandan sites. Overall, yield response to

2004 and 2005 trials in six on-farm sites and two research stations (KARI and NaCRRI) in Kenya and Uganda

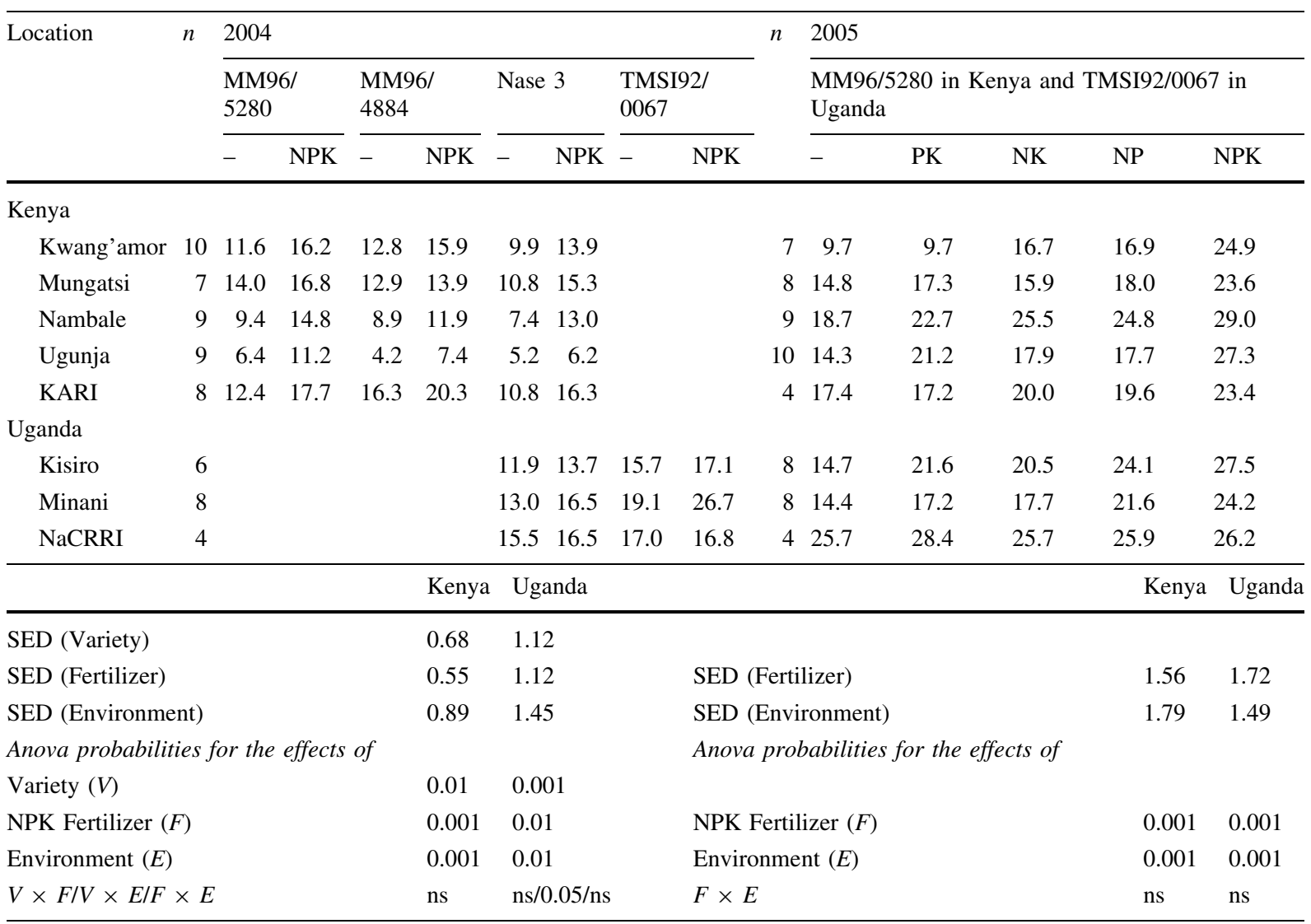

$S E D$ standard error of the difference between means for variety, fertilizer and environment effects

$n s$ non significant 
applied $\mathrm{N}$ and $\mathrm{P}$ was similar, while response to applied $\mathrm{K}$ was smaller $(P<0.05)$. The most limiting nutrients for cassava production were not the same across sites; for example, $\mathrm{N}$ was most limiting in Kwang'amor and KARI, $\mathrm{P}+\mathrm{K}$ in Ugunja and $\mathrm{N}+\mathrm{P}$ in Kisiro and Minani (Table 3; Fig. 2).

NPK fertilizer significantly increased fresh aboveground biomass $(P<0.05)$ and the number of storage roots per plant $(P<0.001)$ in both Kenya and Uganda, but did not affect the individual weight of marketable storage roots and the dry matter content of storage roots (Table 4 and not shown). In Kenya the effect of fertilizer on yield, above-ground biomass and the number of storage roots per plant was more pronounced in 2005 than in 2004, while in Uganda this only held for the effect of fertilizer on yield. In Kenya, but not in Uganda, the apparent harvest index was reduced by fertilizer application (Table 4). Greater above-ground biomass was generally associated with smaller apparent harvest indices, but for a given aboveground biomass, fertilized fields had a higher apparent harvest index than unfertilized fields (Fig. 3).

\section{Cost-benefits of fertilizer use}

A partial gross margin analysis of all trials showed no difference in the benefits of NPK fertilizer use between varieties or countries (data not shown), but fertilizer use was much more profitable in the 2005 trials than in the 2004 trials $(P<0.001$; Table 5) with average marginal revenues of 1,370 and $483 \$ \mathrm{ha}^{-1}$ and Value Cost Ratio's (VCR) of 5.2 and 1.8 , respectively. Overall, $45 \%$ of the fields in the 2004 trials had a VCR $>2$ compared with $83 \%$ of the fields in the 2005 trials $(P<0.001)$. There were large differences in profitability between sites $(P<0.001)$. In the Kenyan on-farm sites, only the combined application of NPK resulted in a VCR that was significantly $(P<0.001)$ larger than 2 , while in the Ugandan on-farm sites application of both NPK and NP resulted in VCR's that were larger than 2 $(P<0.05)$, while adding $\mathrm{K}$ to the NP package did not give economic benefits (data not shown).

Factors that influence response to fertilizer

In the 2005 trials, $\mathrm{RY}_{\mathrm{N}}$ and $\mathrm{RY}_{\mathrm{K}}$ were positively related to SOC $(r=0.51, P<0.001)$ and exchangeable $\mathrm{K}(r=0.40 ; P<0.01)$ respectively, while $\mathrm{RY}_{\mathrm{P}}$ was only weakly associated $(r=0.25)$ with available P (Fig. 4a-c). Yield responses of cassava to NPK fertilizer were negatively associated with SOC, total $\mathrm{N}$, available $\mathrm{P}$, exchangeable $\mathrm{K}$ and the sum of bases (Fig. 5). These relationships were weak $(r=-0.17$ to -0.29$)$, but significant $(P<0.05)$, and were stronger for the 2005 data $(r=-0.52$ to -0.61 ; $P<0.001)$ than for the 2004 data $(r=-0.05$ to -0.11 ), except for available P. Soil $\mathrm{pH}$ and texture were not associated with fertilizer response in cassava. Even on soils with low nutrient levels,
Fig. 2 Relative fresh cassava yield in absence of $\mathrm{N}, \mathrm{P}$ and $\mathrm{K}$ for the 2005 trials in eight sites in Kenya and Uganda. SED stands for SE of the Difference of the means for relative $\mathrm{N}, \mathrm{P}$ and $\mathrm{K}$ yields. Bars indicated with ' $*$ ' are significantly different from the fully fertilized control (relative yield $=1$ ) at $P<0.05$

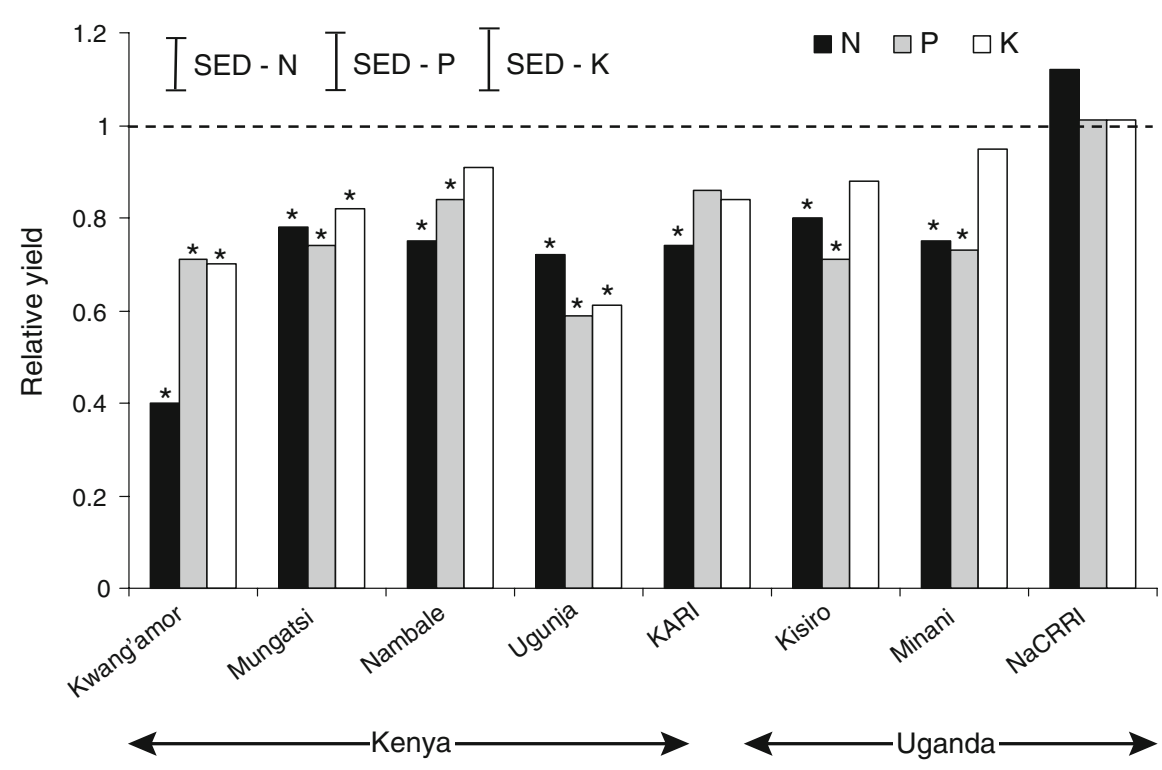


Table 4 Effect of NPK fertilizer (100:22:83 $\mathrm{kg} \mathrm{ha}^{-1} \mathrm{~N}: \mathrm{P}: \mathrm{K}$; '-’ signifies no fertilizer) on selected yield components of MM95/5280 and I92/0067 in the 2004 and 2005 trials in eight sites in Kenya and Uganda

\begin{tabular}{|c|c|c|c|c|c|c|c|c|c|}
\hline \multicolumn{3}{|c|}{ Yield components } & \multirow{2}{*}{$\begin{array}{l}\text { Yield } \\
\left(\mathrm{t} \mathrm{ha}^{-1}\right)\end{array}$} & \multirow{2}{*}{$\begin{array}{l}\text { Above- } \\
\text { ground } \\
\text { biomass } \\
\left(\mathrm{t} \mathrm{ha}^{-1}\right)\end{array}$} & \multirow[t]{2}{*}{ HI (-) } & \multirow{2}{*}{$\begin{array}{l}\text { \# storage } \\
\text { roots } \\
\text { plant }^{-1}(-)\end{array}$} & \multirow{2}{*}{$\begin{array}{l}\text { Weight } \\
\text { marketable } \\
\text { roots }(\mathrm{g})\end{array}$} & \multirow{2}{*}{$\begin{array}{l}\% \\
\text { marketable } \\
\text { roots }(\%)\end{array}$} & \multirow{2}{*}{$\begin{array}{l}\text { Dry } \\
\text { matter } \\
(\%)\end{array}$} \\
\hline Trial & Fertilizer & $n$ & & & & & & & \\
\hline \multicolumn{10}{|l|}{ Kenya } \\
\hline \multirow[t]{2}{*}{2004} & - & 42 & 10.6 & 11.4 & 49 & 5.4 & 277 & 65 & 36.9 \\
\hline & NPK & 42 & 15.2 & 17.7 & 48 & 8.0 & 276 & 63 & 37.4 \\
\hline \multirow[t]{2}{*}{2005} & - & 38 & 14.7 & 10.4 & 59 & 6.0 & 374 & 66 & 38.6 \\
\hline & NPK & 38 & 26.0 & 24.4 & 53 & 10.4 & 392 & 65 & 39.6 \\
\hline SED (Fertilizer) & & & 0.92 & 1.35 & 1.6 & 0.33 & 13 & 1.9 & 0.67 \\
\hline SED (Year) & & & 0.92 & 1.35 & 1.6 & 0.34 & 13 & 1.9 & 0.67 \\
\hline \multicolumn{10}{|c|}{ Anova probabilities for the effects of } \\
\hline Fertilizer $(F)$ & & & 0.001 & 0.001 & 0.05 & 0.001 & ns & ns & ns \\
\hline Year $(Y)$ & & & 0.001 & 0.05 & 0.001 & 0.001 & 0.001 & ns & 0.01 \\
\hline$F \times Y$ & & & 0.001 & 0.01 & ns & 0.01 & ns & ns & ns \\
\hline \multicolumn{10}{|l|}{ Uganda } \\
\hline \multirow[t]{2}{*}{2004} & - & 18 & 17.3 & 28.2 & 40 & 5.1 & 583 & 76 & 33.6 \\
\hline & NPK & 18 & 20.4 & 34.3 & 40 & 5.9 & 581 & 74 & 34.2 \\
\hline \multirow[t]{2}{*}{2005} & - & 20 & 17.0 & 21.0 & 46 & 4.3 & 581 & 76 & 40.3 \\
\hline & NPK & 20 & 25.9 & 29.4 & 48 & 6.6 & 640 & 75 & 42.2 \\
\hline SED (Fertilizer) & & & 1.32 & 2.95 & 2.1 & 0.39 & 40 & 2.7 & 0.95 \\
\hline SED (Year) & & & 1.31 & 2.95 & 2.1 & 0.39 & 40 & 2.7 & 0.95 \\
\hline \multicolumn{10}{|c|}{ Anova probabilities for the effects of } \\
\hline Fertilizer $(F)$ & & & 0.001 & 0.05 & ns & 0.001 & ns & ns & ns \\
\hline Year $(Y)$ & & & 0.05 & 0.05 & 0.01 & ns & ns & ns & 0.001 \\
\hline$F \times Y$ & & & 0.05 & ns & ns & ns & ns & ns & ns \\
\hline
\end{tabular}

a $S E D$ Standard error of the difference between means for fertilizer and year effects $n s$ non significant

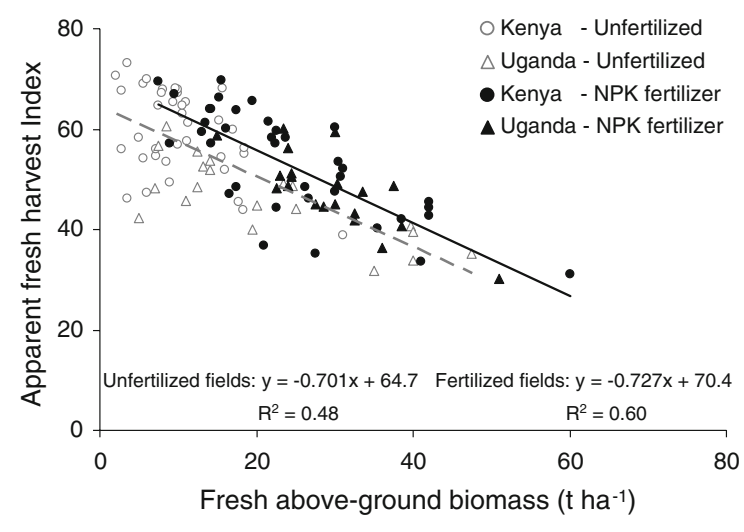

Fig. 3 Relationship between fresh above-ground biomass and apparent fresh harvest index (not taking into account fallen leaves) for the unfertilized and fertilized plots in the 2005 trials in eight sites in Kenya and Uganda responses to fertilizer varied strongly (i.e. on soils with a SOC content of $<10 \mathrm{~g} \mathrm{~kg}^{-1}$, responses ranged from -8.6 to $24.4 \mathrm{t} \mathrm{ha}^{-1}$ ). Considering a VCR of 2 (which translates into a yield increase of $4.0 \mathrm{t}$ ha) as a minimum requirement for fertilizer adoption, responses to fertilizer are likely to be too small to stimulate adoption if $\mathrm{SOC}>20 \mathrm{~g} \mathrm{~kg}^{-1}$; available $\mathrm{P}$ $>13 \mathrm{mg} \mathrm{kg}^{-1}$; exchangeable $\mathrm{K}>1.0 \mathrm{cmol} \mathrm{kg}^{-1}$ and $\mathrm{Ca}>10 \mathrm{cmol} \mathrm{kg}^{-1}$ (Fig. 5a-d).

Across years, yield response to NPK fertilizer was best correlated to total rainfall and rainfall during the first 3 months $(r=0.31 ; P<0.01$ and 0.18 ; $P<0.05$, respectively). Although correlations were weak, there was a clear indication that larger maximum yield responses to NPK fertilizer occurred with higher rainfall in both years (Fig. 6a, b), when 
Table 5 Partial gross margin analysis for NPK fertilizer use (100:22:83 $\left.\mathrm{kg} \mathrm{ha}^{-1} \mathrm{~N}: \mathrm{P}: \mathrm{K}\right)$ for the 2004 and 2005 trials in eight sites in Kenya and Uganda

\begin{tabular}{|c|c|c|c|c|c|c|}
\hline Location & $n$ & $\begin{array}{l}\text { Marginal yield } \\
\left(\mathrm{t} \mathrm{ha}^{-1}\right)\end{array}$ & $\begin{array}{l}\text { Marginal costs } \\
\left(\$ \mathrm{ha}^{-1}\right)\end{array}$ & $\begin{array}{l}\text { Marginal } \\
\text { revenue } \\
\left(\$ \mathrm{ha}^{-1}\right)\end{array}$ & $\operatorname{VCR}^{\mathrm{a}}(-)$ & $\begin{array}{l}\text { Fields with } \\
\text { VCR }>2(\%)\end{array}$ \\
\hline \multicolumn{7}{|l|}{2004} \\
\hline \multicolumn{7}{|l|}{ Kenya } \\
\hline Kwang'amor & 28 & 3.9 & 266 & 520 & 2.0 & 53 \\
\hline Mungatsi & 21 & 2.8 & 266 & 374 & 1.4 & 43 \\
\hline Nambale & 27 & 4.7 & 266 & 626 & 2.4 & 41 \\
\hline Ugunja & 24 & 3.0 & 266 & 406 & 1.5 & 38 \\
\hline KARI & 24 & 4.9 & 266 & 656 & 2.5 & 63 \\
\hline \multicolumn{7}{|l|}{ Uganda } \\
\hline Minani & 12 & 5.3 & 251 & 620 & 2.5 & 50 \\
\hline Kisiro & 10 & 1.6 & 251 & 184 & 0.7 & 30 \\
\hline NaCRRI & 8 & 0.4 & 251 & 43 & 0.2 & 13 \\
\hline Mean & 154 & 3.7 & 363 & 483 & 1.8 & 45 \\
\hline \multicolumn{7}{|l|}{2005} \\
\hline \multicolumn{7}{|l|}{ Kenya } \\
\hline Kwang'amor & 7 & 15.3 & 266 & 2,042 & 7.7 & 100 \\
\hline Mungatsi & 7 & 8.9 & 266 & 1,191 & 4.5 & 86 \\
\hline Nambale & 7 & 10.3 & 266 & 1,379 & 5.2 & 71 \\
\hline Ugunja & 9 & 14.0 & 266 & 1,877 & 7.0 & 100 \\
\hline KARI & 4 & 6.0 & 266 & 804 & 3.0 & 75 \\
\hline \multicolumn{7}{|l|}{ Uganda } \\
\hline Minani & 7 & 9.7 & 251 & 1,139 & 4.5 & 71 \\
\hline Kisiro & 7 & 12.9 & 251 & 1,519 & 6.1 & 100 \\
\hline NaCRRI & 4 & 0.5 & 251 & 57 & 0.2 & 25 \\
\hline Mean & 52 & 10.6 & 261 & 1,370 & 5.2 & 83 \\
\hline \multicolumn{7}{|c|}{ Anova probabilities for the effects of } \\
\hline Environment $(E)$ & - & 0.001 & - & 0.001 & 0.001 & $\mathrm{~ns}^{\mathrm{b}}$ \\
\hline Year $(Y)$ & - & 0.001 & - & 0.001 & 0.001 & 0.001 \\
\hline$E \times Y$ & - & 0.001 & - & 0.001 & 0.001 & - \\
\hline
\end{tabular}

\footnotetext{
a Value cost ratio

b Chi-square statistics

$n s$ non significant
}

total rainfall $>1,500 \mathrm{~mm}$ or rainfall from 0 to 3 MAP $>400 \mathrm{~mm}$. Similar trends were observed for the response in above-ground biomass and the change in the number of roots per plant due to NPK fertilizer application (Fig. 6c-f). No clear trends were observed across years for the apparent fresh harvest index, individual storage root weight and the dry matter content of storage roots and rainfall.

Overall, better weed management was associated ( $r=0.34 ; P<0.001$ ) with higher cassava yields in unfertilized plots up to a weed management score of 3.5 (Fig. 7a). In fertilized plots, though, no relation was found between weed management and yields (Fig. 7b). A different picture was observed in the Kenya 2004 trials. In these trials, better weed management was strongly associated with higher yields in both the unfertilized and fertilized plots ( $r=0.46 ; P<0.001$ in both cases) up to the highest weed management score (5). In the unfertilized plots of the Kenyan trials, plant width of MM96/5280 at 3 

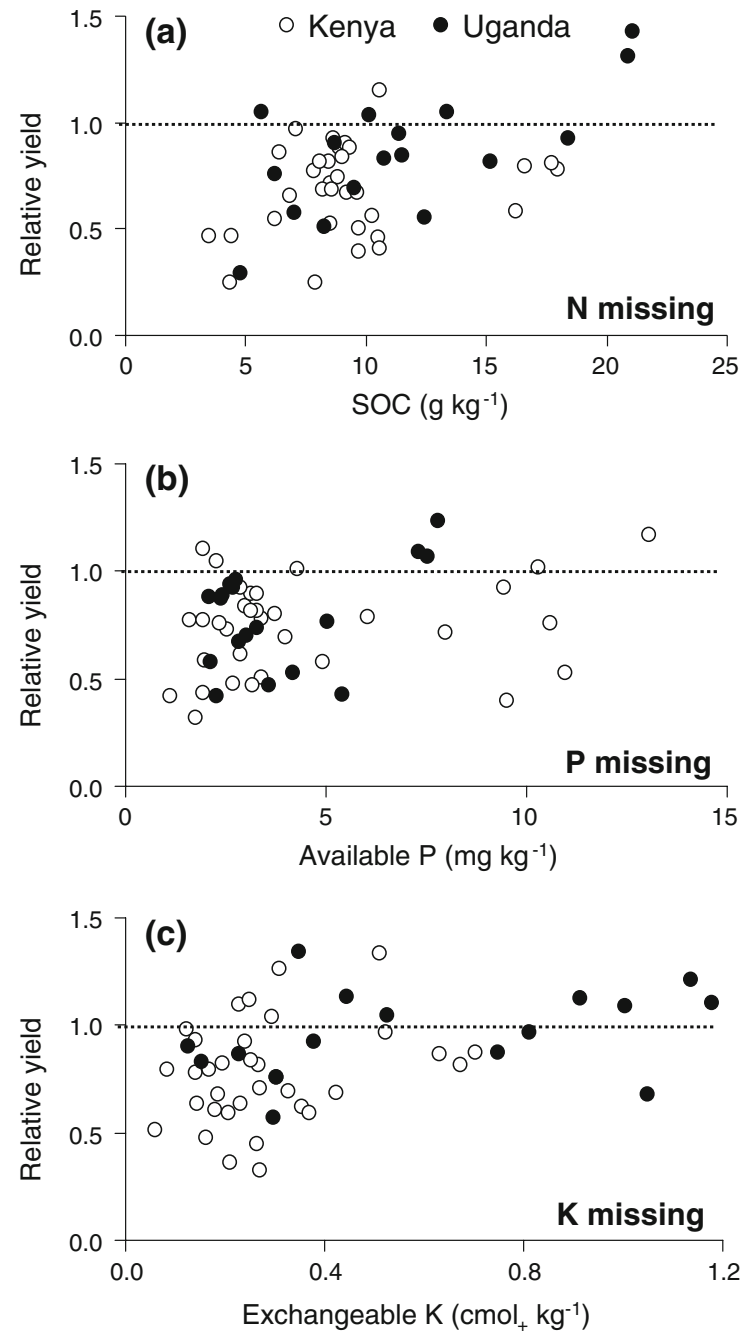

Fig. 4 Relative cassava yields from the 2005 trials in Kenya and Uganda without $\mathrm{N}, \mathrm{P}$ and $\mathrm{K}$ in relation to a SOC; b available $\mathrm{P}$; and $\mathbf{c}$ exchangeable $\mathrm{K}$, respectively. Relative yields are calculated as missing $\mathrm{N}, \mathrm{P}$ or $\mathrm{K}$ yields over yields with full nutrient (NPK) applications of $\mathrm{N}=100 \mathrm{~kg} \mathrm{ha}^{-1}$; $\mathrm{P}=22 \mathrm{~kg} \mathrm{ha}^{-1}$; and $\mathrm{K}=83 \mathrm{~kg} \mathrm{ha}^{-1}$. The dashed line indicates the control yield (no response to applied $\mathrm{N}, \mathrm{P}$ or $\mathrm{K}$ )

MAP was similar in both trial years, but at 6 MAP plants were $19 \%$ wider in 2005 than in 2004 $(P<0.001$; Fig. 8). In the fertilized plots of the same trials, plants were already $21 \%$ wider at 3 MAP $(P<0.001)$ and $23 \%$ wider $(P<0.001)$ at 6 MAP in 2005 than in 2004. In 2004, fertilizer use increased plant width of MM96/5280 by $14 \%$ at 3 MAP and by $28 \%$ at 6 MAP $(P<0.001)$, while in 2005 fertilizer used increased plant width by 33 and $43 \%$ at 3 and 6 MAP, respectively $(P<0.001)$. Full ground cover was thus reached earlier, contributing to more effective weed suppression through light competition, in the fertilized plots than in the unfertilized plots and in 2005 than in 2004.

Factors that did not influence response to fertilizer

Although yields varied significantly $(P<0.001)$ between varieties, the yield response to NPK fertilizer was similar for the four varieties used in the 2004 trials (Table 3). Similar results were found for the aboveground biomass, number of storage roots per plant, individual weight of marketable storage roots and dry matter content of the storage roots (data not shown).

No effects of pest and disease pressure on fertilizer response were seen. Average yield response to fertilizer in the $25 \%$ of the fields that were least affected by bacterial blight, green mites and cassava mosaic disease was similar to average yield response to fertilizer in the $25 \%$ most affected fields by these pests and diseases. No analysis was done for anthracnose as $>95 \%$ of the fields had low severity scores (AUSiPC $<50$ ). NPK fertilizer use decreased green mites on all varieties $(P<0.01)$, but increased cassava mosaic disease severity $(P<0.01)$ on varieties that are susceptible to this virus, i.e. Nase 3 and MM96/4884, slightly increased anthracnose on MM96/5280 and Nase $3(P<0.05)$ and slightly increased bacterial blight $(P<0.05)$, except on I92/ 0067 (Fig. 9a-d).

Although harvesting at an older age was weakly associated with higher yields in both years $(r=0.25$ and 0.22 for 2004 and 2005, respectively), no effects of harvest age on fertilizer response were found.

\section{Discussion}

NPK fertilizer application resulted in strong increases in cassava yield in the two years of the study. Response to fertilizer was highly variable between years and sites and was affected by soil fertility, rainfall and weed management. Fertilizer response in our trials was not influenced by variety choice, pest and disease pressure and harvest age. As nutrient demands did not vary between the varieties we used in 2004, we subsequently focused on identifying the 
Fig. 5 Fresh yield response to NPK fertilizer (100:22:83 $\left.\mathrm{kg} \mathrm{ha}^{-1} \mathrm{~N}: \mathrm{P}: \mathrm{K}\right)$ for the 2004 and 2005 trials in eight sites in Kenya and Uganda in relation to a SOC; $\mathbf{b}$ available $\mathrm{P}$; $\mathbf{c}$ exchangeable $\mathrm{K}$; and $\mathbf{d}$ sum of exchangeable bases $(\mathrm{K}, \mathrm{Ca}$, $\mathrm{Mg})$ in the topsoil $(0$ $20 \mathrm{~cm})$. The solid lines indicate a VCR of 2 (i.e. yield response of $4 \mathrm{tha}^{-1}$ )
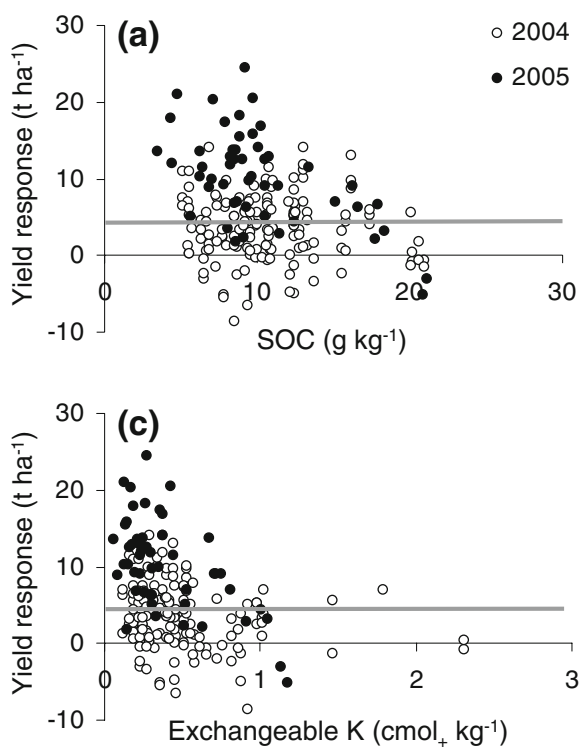

Fig. 6 Effect of rainfall on response of yield, aboveground biomass and number of storage roots per plant to NPK fertilizer (100:22:83 $\left.\mathrm{kg} \mathrm{ha}^{-1} \mathrm{~N}: \mathrm{P}: \mathrm{K}\right)$. Fresh cassava yield response (a, b), fresh above-ground biomass response $(\mathbf{c}, \mathbf{d})$ and change in number of storage roots per plant $(\mathbf{e}, \mathbf{f})$ in the 2004 and 2005 trials in Kenya and Uganda against total rainfall $(\mathbf{a}, \mathbf{c}, \mathbf{e})$ and rainfall during $0-3$ months after planting $(\mathbf{b}, \mathbf{d}, \mathbf{f})$. Lines indicate boundary lines (see text for further explanation)
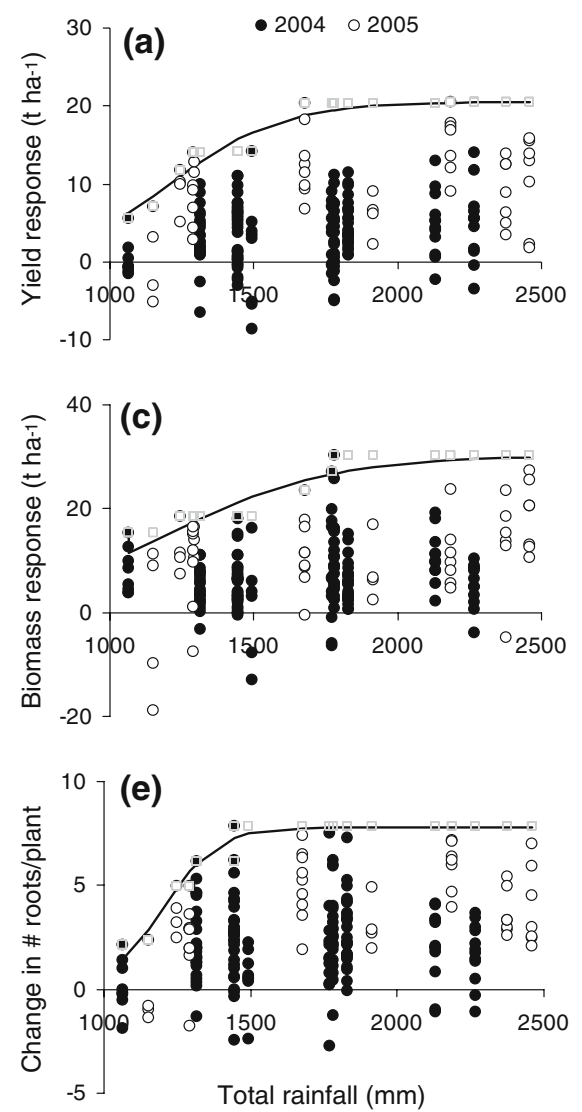
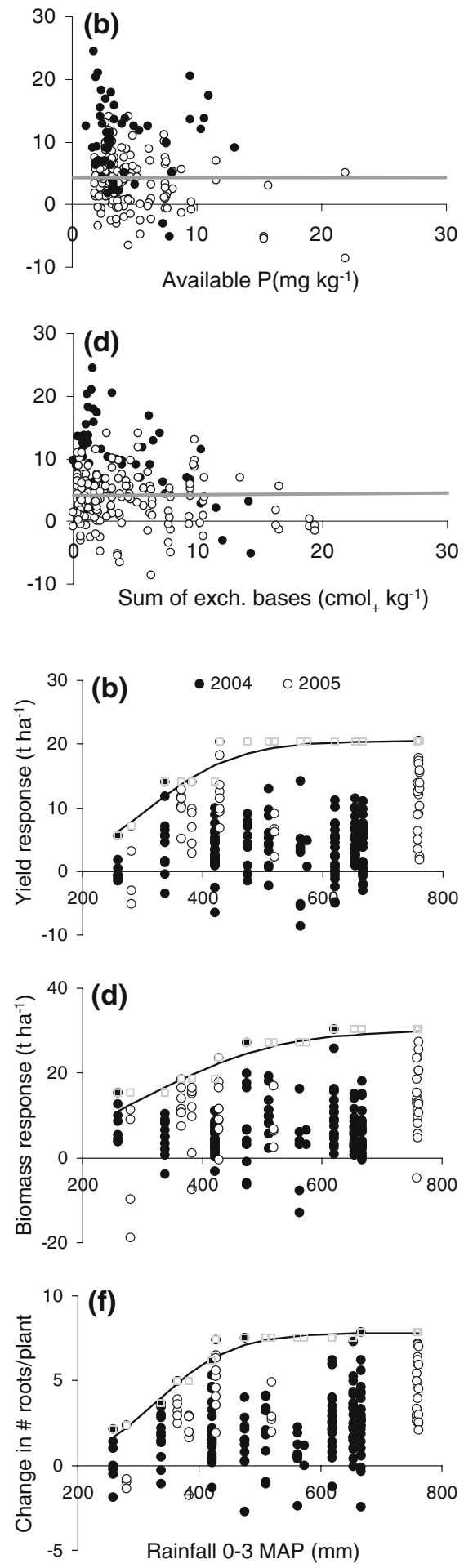

main nutrients limiting cassava production in 2005 . Cassava yields in farmers' fields in Kenya and Uganda were limited by both $\mathrm{N}$ and $\mathrm{P}$, while $\mathrm{K}$ was only limiting production in Kenya.
Variability in unfertilized cassava yields

Unfertilized cassava yields varied strongly between sites and years (Table 3). Yields were much lower in 
Fig. 7 Effects of weed management on fresh cassava yield in unfertilized treatments $(\mathbf{a}, \mathbf{c})$ and yield with NPK fertilizer (100:22:83 kg ha $\left.{ }^{-1} \mathrm{~N}: \mathrm{P}: \mathrm{K}\right)$ (b, d) for the 2004 and 2005 trials in Kenya and Uganda (a, b) and for the 2004 Kenyan trials separately (c, d). Farmer weed management during the growing cycle was scored from very poor (1) to very good (5). Lines indicate boundary lines (see text for further explanation)
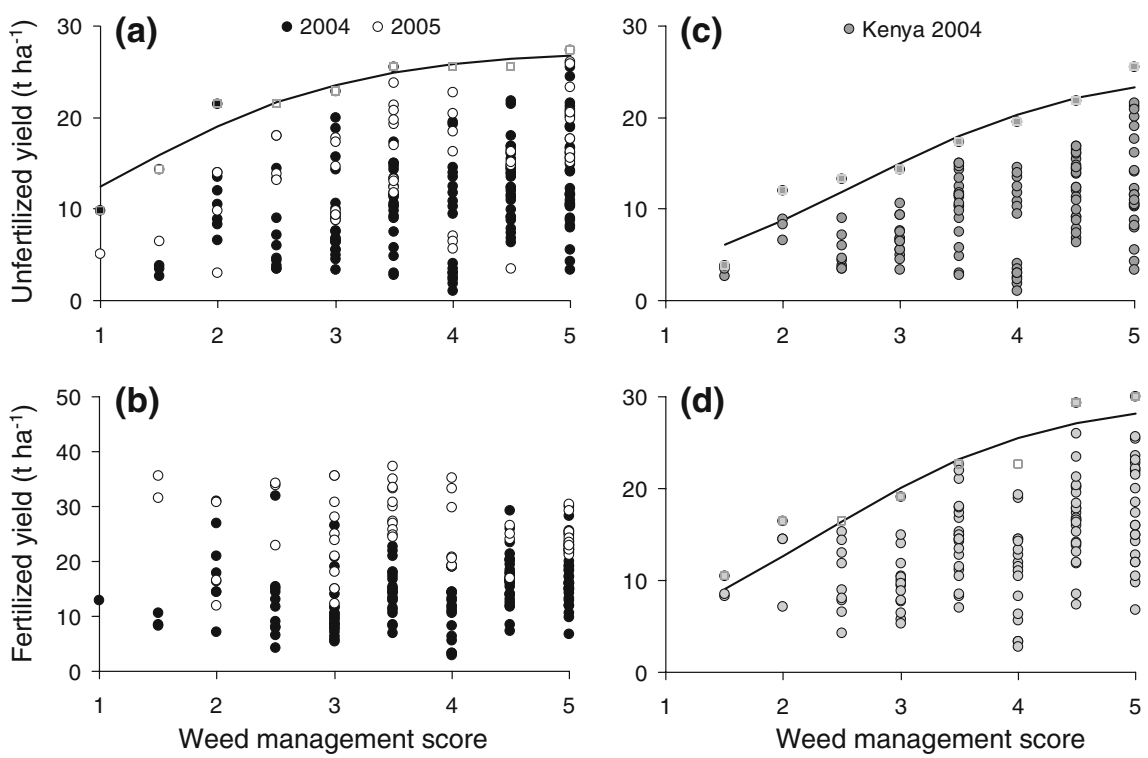

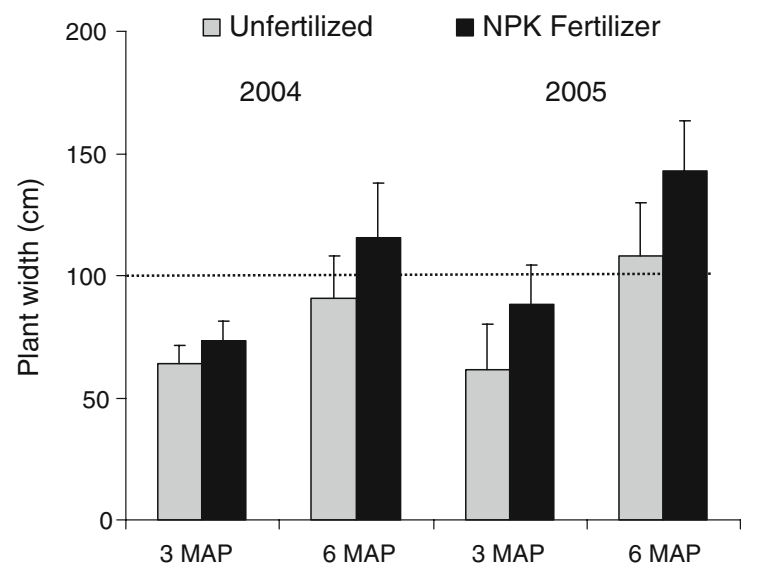

Fig. 8 Effect of NPK fertilizer (100:22:83 $\left.\mathrm{kg} \mathrm{ha}^{-1} \mathrm{~N}: \mathrm{P}: \mathrm{K}\right)$ on average plant width of MM96/5280 in the 2004 and 2005 Kenyan on-farm trials at 3 and 6 months after planting. Plant width was measured on the twenty plants in the net harvest area. As plant spacing was $1 \times 1 \mathrm{~m}\left(10,000\right.$ plants ha $\left.{ }^{-1}\right)$, width corresponds directly to percentage soil cover and the dashed line indicates full ground cover

2004 than in 2005, indicating generally less favourable growing conditions for cassava during the first set of trials. Lower yields in the 2004 Kenya trials can partially be explained by the early harvest at 11 MAP and by the relatively low amounts of rainfall received during 2-4 months after planting (Fig. 1) as a water deficit during 1-5 months after planting may reduce storage root yields by up to 32-60\% (Alves 2002). Unfertilized cassava yields in the trials were much higher than farmer estimates of average cassava yields in the same sites in Kenya $\left(7.0 \mathrm{t} \mathrm{ha}^{-1}\right)$ and Uganda (11.2 $\mathrm{t} \mathrm{ha}^{-1}$ ) (Fermont et al. 2008). They were also generally, but not always, higher than the average yields reported by FAO (2008) for Kenya $\left(9.1 \mathrm{t} \mathrm{ha}^{-1}\right)$ and Uganda $\left(14.4 \mathrm{tha}^{-1}\right)$ in 2005. The use of improved varieties, that are resistant to cassava mosaic disease, sole cropping and timely planting at the start of the growing season will have contributed to the higher yields obtained in the trials.

\section{Variability in fertilizer response}

NPK fertilizer application increased cassava yields significantly in both years (cf. Table 3 ). The response to NPK fertilizer of MM96/5280 and TMSI92/0067, varieties that were used in both sets of trials, was much stronger in the 2005 than in the 2004 trials (Table 4), when rainfall distribution was less favourable. Total $\mathrm{N}$ and exchangeable $\mathrm{K}$ contents in the soils of the study sites were higher for the 2004 than for the 2005 trials (Table 2). This likely reduced the overall response to applied $\mathrm{N}$ and $\mathrm{K}$ (Fig. 4) in 2004. The use efficiency of $\mathrm{N}$ was perhaps also lower in 2004, when fertilizer top dressings were applied as a surface application in contrast to 2005 when top dressings were incorporated in the soil. Surface application of fertilizer may result in $\mathrm{N}$ being more prone to volatilization losses (Mahli et al. 1996). Even on infertile soils, with SOC, $\mathrm{P}$ and/or K below the critical 
Fig. 9 Effect of NPK fertilizer (100:22:83 $\mathrm{kg} \mathrm{ha}^{-1}$ $\mathrm{N}: \mathrm{P}: \mathrm{K})$ on a bacterial blight; b green mites; c anthracnose disease; and $\mathbf{d}$ cassava mosaic disease for four varieties in the 2004 and 2005 trials in Kenya and Uganda. Pest and disease pressure in unfertilized and fertilized plots is expressed as Area Under Severity index Progress curve (AUSiPC). See text for more details
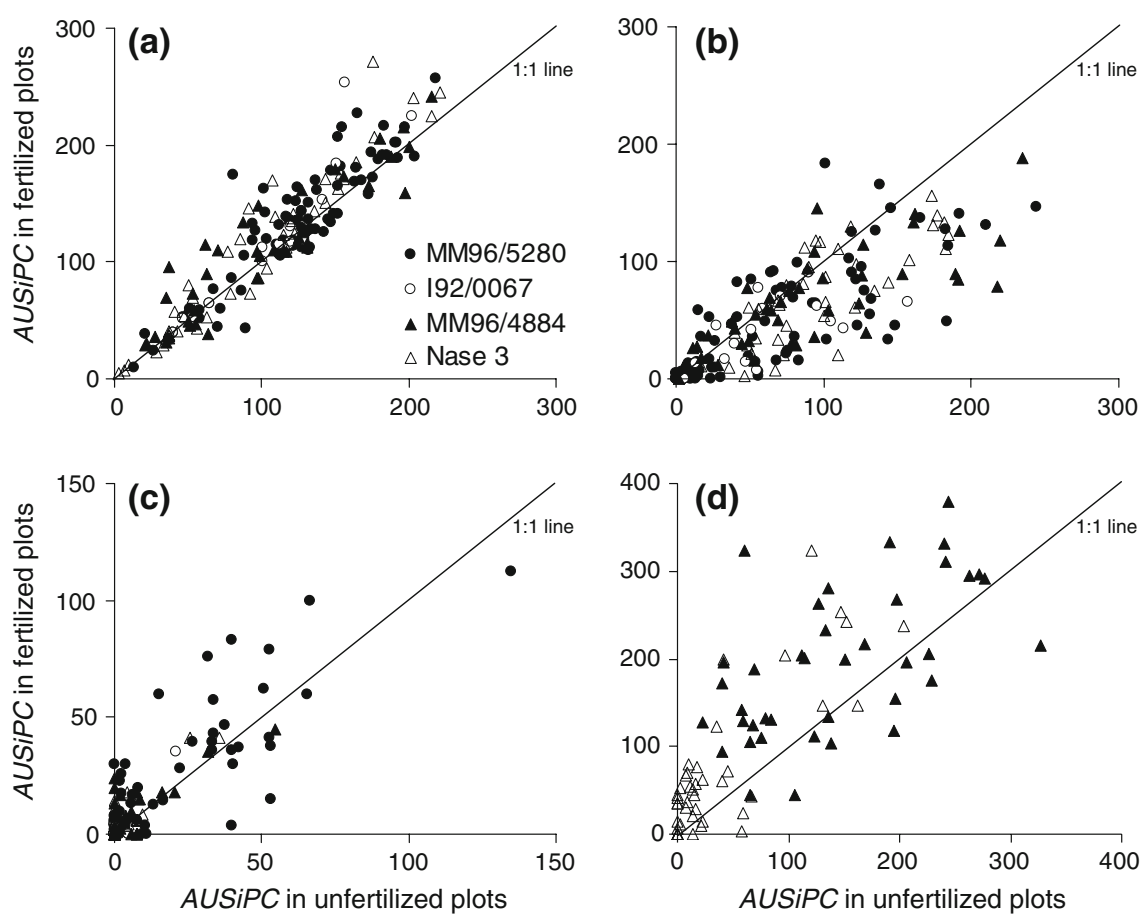

ranges for cassava proposed by Howeler (2002), response to fertilizer was extremely variable (Figs. 4, 5). This may be due to nutrient limitations other than $\mathrm{N}, \mathrm{P}$ or $\mathrm{K}$, variation in efficiency of mycorrhizal associations between fields (Howeler 2002), and/or interactions between multiple constraints.

Yield increases due to fertilizer application were the result of an increased sink capacity (i.e. increased number of storage roots per plant), an increased source supply (i.e. increased above-ground biomass) and a slightly higher dry matter partitioning to the roots at a given above-ground biomass (Fig. 3). An increase in the number of storage roots per plant in response to fertilizer application has also been observed by Pellet and El-Sharkawy (1993) and Kasele (1983). Cassava yield components that are of interest for commercial cassava producers (dry matter, average root weight, $\%$ marketable roots) were not affected by fertilizer use. Root starch content may decrease with $\mathrm{N}$ fertilization and increase with K fertilization (Howeler 2002, 1998; Obigbesan and Matuluka 1977).

\section{Nutrient limitations}

Zink deficiency symptoms were observed on cassava leaves during the first 3-4 MAP in three quarters of the farmers' fields in the Ugandan site with the highest sand content (Minani). High $\mathrm{P}$ availability through fertilizer application can induce $\mathrm{Zn}$ deficiencies, most likely through precipitation of $\mathrm{ZnPO}_{4}$ (Lozano et al. 1981; Howeler, pers. comm. 2006). In serious cases, plant vigour in fertilized plots was strongly retarded, especially during early growth and resulted in negative responses to applied fertilizer.

Major nutrient limitations to cassava production varied between sites in Uganda and Kenya (Fig. 2). In western Kenya the combined application of NPK gave highest returns to investment, while in Uganda application of $\mathrm{K}$ was not economic (Table 5). Howeler and Cadavid (1990) also found that limitations to $\mathrm{N}, \mathrm{P}$ and $\mathrm{K}$ varied between sites in Colombia, but pointed out that $\mathrm{K}$ became the limiting element when cassava was grown continuously in the same field. Similar conclusions were drawn for Benin by Carsky and Toukourou (2005). In our study, the Kenyan soils had lower amounts of soil nutrients than the Ugandan soils. Soils in western Kenya are generally considered as degraded as a consequence of long-term cultivation with no or little carbon and nutrient inputs (Tittonell et al. 2008).

Responses expressed as $\mathrm{kg}$ fresh cassava per $\mathrm{kg}$ nutrient applied were larger than those found on low fertility soils in Benin using an $\mathrm{N}: \mathrm{P}: \mathrm{K}$ fertilizer 
application of 60:16:138 (23, 88 and $10 \mathrm{~kg}$ cassava per $\mathrm{kg} \mathrm{N}, \mathrm{P}$ and $\mathrm{K}$ applied, respectively; calculated from Carsky and Toukourou (2005)), and similar to those found in 22 sites across Colombia using an $\mathrm{N}: \mathrm{P}: \mathrm{K}$ fertilizer application of 100:50:100 (92, 184 and $92 \mathrm{~kg}$ cassava per $\mathrm{kg} \mathrm{N}, \mathrm{P}$ and $\mathrm{K}$ applied, respectively; calculated from Howeler and Cadavid (1990)). Based on empirical evidence, critical soil nutrient contents for cassava were estimated to range between 4 and $8 \mathrm{mg} \mathrm{kg}^{-1}$ for available $\mathrm{P}$ (Bray I), $0.08-0.18 \mathrm{cmol}_{+} \mathrm{kg}^{-1}$ for exchangeable $\mathrm{K}\left(\mathrm{NH}_{4}{ }^{-}\right.$ acetate) and around $3.1 \%$ for soil organic matter (or $18 \mathrm{~g} \mathrm{~kg}^{-1} \mathrm{SOC}$ ) for cassava in Asia, Latin America and Nigeria (Howeler 2002). C contents in the majority of the soils in our study were below $18 \mathrm{~g} \mathrm{~kg}^{-1}$, and significant responses to applied $\mathrm{N}$ up to this critical value were observed (cf. Figs. 2, 4, 5). Although approximately half of the soils in our study had available $\mathrm{P}$ contents below the critical range indicated above, we observed significant responses to applied $\mathrm{P}$ in soils with somewhat greater $\mathrm{P}$ availability (Fig. 4) and did not observe better responses in soils with less $\mathrm{P}$ available. Approximately two-thirds of the soils in our study had exchangeable $\mathrm{K}$ values above the critical $\mathrm{K}$ range of reference, but response to $\mathrm{K}$ was observed in soils with up to $0.4 \mathrm{cmol}_{+}$ $\mathrm{K} \mathrm{kg}^{-1}$ (cf. Fig. 4). These results question the validity of the critical thresholds referred to outside the conditions (of soil, climate and farming systems) from which they were derived.

\section{Water stress}

The observed variability in fertilizer response was not only related to differences in native nutrient supply but was also due to differences in water stress during early plant growth. In case rainfall during the first 3 MAP was limited, both the increase in source (i.e. above-ground biomass) and sink capacity (i.e. number of storage roots per plant) due to fertilizer were less than if rainfall during initial growth was sufficient (Fig. 6d, f). This translated in reduced yield responses to fertilizer (Fig. 6b). Water stress during early growth (1-5 months) is known to reduce the number of storage roots per plant and has severe implications for root yield as this period is critical for storage root initiation (Duque et al. 2008; Connor et al. 1981). Seasonal water stress after 3-4 MAP did not affect fertilizer response (De Tafur et al. 1997).
Cassava exhibits strong defence mechanisms against prolonged seasonal droughts, which include, amongst others, partial stomatal closure, ability to maintain reasonable net photosynthetic rates, leaf area reduction, leaf folding and extraction of water from deeper soil layers. In addition the crop has the ability to recover from a seasonal drought period and compensate for its adverse effects through an increase in leaf canopy area and by higher photosynthetic rates in the newly developed leaves (El-Sharkawy 2007, 2004; Alves 2002; De Tafur et al. 1997). Thus, water stress before 3-4 MAP reduces the response to fertilizer as it limits the formation of additional sink (i.e. storage roots) and source (i.e. above-ground biomass) capacity, while seasonal water stress after 3-4 months does not affect fertilizer response as the source capacity is able to quickly recover from the experienced stress and can fulfil the carbohydrate demand of the sink.

\section{Weed competition}

As expected, weed management had a positive effect on the yields of unfertilized cassava fields (Fig. 7a) and was more important when plant vigour in early growth stages is poor (Figs. 7c, 8). The slow initial growth of cassava renders the crop particularly vulnerable to weed competition in the first 3 months after planting and uncontrolled weed growth may reduce yields by 50-65\% (Melifonwu 1994; Doll et al. 1982, quoted in Leihner 2002). Once complete ground cover is reached, cassava shades out weeds (Melifonwu 1994). Plants that received fertilizer grew faster, enabling the crop to reach complete ground cover earlier (Fig. 8; Pellet and El-Sharkawy 1997). Consequently, weeds were shaded out earlier in fertilized plots and weed management in fertilized cassava fields only paid off when plant development in early growth stages was slow (Fig. 7b, d). Considering that in East Africa farmers weed cassava fields on average 4.5 times and spend $60 \%$ of all labour used on cassava on weeding (Fermont, unpublished), fertilizer use has a considerable potential to reduce labour requirements of cassava. This potential reduction in labour for weeding through the introduction of fertilizer was not taken into account in the economic analysis (Table 5). With fertilizer use, the canopy closes within approximately 3 MAP (Fig. 8) and the number op weed operations could possibly be reduced from 4.5 to 2 . This could potentially improve the VCR 
by approximately $26 \%$ and translate into a reduction of the economic threshold for fertilizer use from a yield response of four $\mathrm{tha}^{-1}$ to three $\mathrm{tha} \mathrm{ha}^{-1}$.

\section{Effect of fertilizer on pests and diseases}

The use of balanced NPK fertilizer has been recommended for the control of pests and diseases, in particular for bacterial blight, as it encourages plant vigour (Fig. 8) and thus reduces the effect of early attacks in the rainy season when plants are still vulnerable (Persley et al. 1976). The effect of fertilizer on pest and diseases in our trials was variable and apparently depended on local conditions. Overall, fertilizer decreased green mite pressure on all varieties, but increased cassava mosaic virus on susceptible varieties and slightly increased bacterial blight and anthracnose pressure (Fig. 9a-d). Previous reports on the effect of fertilizer on bacterial blight and mosaic disease were contradictory. Some authors (Mollard 1987; Obigbesan and Matuluka 1977) reporting an increase, others (Zinsou et al. 2004; Sseruwagi et al. 2003) reporting no effect of fertilizer, while Odurukwe and Arene (1980) and Adeniji and Obigbesan (1976) found a decrease due to fertilizer application. Nonetheless, changes in pest and disease pressure due to fertilizer were small in our trials and did not affect the yield response of cassava to fertilizer use.

\section{Conclusions}

The response of cassava to fertilizer in Kenya and Uganda was governed by soil fertility conditions, rainfall during initial growth stages and weed management in case of slow initial plant growth. The high variability in fertilizer response, even on infertile soils, is an indication that interactions between these factors are important and should be considered when developing fertilizer recommendations for cassava. Although profitability of fertilizer use varied strongly between sites and years, the high returns to investment in 2005 (90\% of the fields had a VCR >2) shows that there is a huge scope to use fertilizer to increase cassava productivity and profitability on smallholder farms in Africa. This is so even with the current high fertilizer and relatively low cassava prices. Fertilizer use did not negatively affect cassava properties that are of interest in commercial cassava production (e.g. dry matter content, root weight, percentage of marketable roots) nor did it considerably change pest and disease pressures. Various practices may improve the profitability of fertilizer. They include (1) reducing the risk of water stress during the first 3-4 MAP through planting at the start of the rains and promotion of management practices that improve infiltration of rainwater and/or reduce evaporation from the soil surface; (2) proper weed management in case of slow plant development; (3) resolving possible micro-nutrient deficiencies (e.g. $\mathrm{Zn}$ ); and (4) determining the economic optimal rate of $\mathrm{NP}(\mathrm{K})$ fertilizer. The expected development and increases in prices of food, feed and especially industrial markets for ethanol and starch in Africa will strongly increase the demand for cassava and will require farmers to adopt technology packages that improve both productivity and profitability of cassava production. It is without doubt that fertilizer should be a key component of such packages in Africa, as it is currently in Asia and Latin America.

Acknowledgments We are grateful to all Kenyan and Ugandan farmers who enthusiastically collaborated in this study. We thank Josephine Lubondi, Annet Babirye and Joseph Kizimi (IITA) for their contributions to the field work and Hannington Obiero of the Kenyan Agricultural Research Institute and Dr. Anton Bua of the National Agricultural Research Organization, Uganda for their support. We are grateful to the Dutch Ministry of Development Cooperation and the International Institute of Tropical Agriculture (IITA) for funding.

Open Access This article is distributed under the terms of the Creative Commons Attribution Noncommercial License which permits any noncommercial use, distribution, and reproduction in any medium, provided the original author(s) and source are credited.

\section{References}

Adeniji MO, Obigbesan GO (1976) The effect of potassium nutrition on the bacterial wilt of cassava. Niger J Plant Prot 2:1-3

Alicai T, Omongo CA, Maruthi MN, Hillocks RJ, Baguma Y, Kawuki R, Bua A, Otim-Nape GW, Colvin J (2007) Reemergence of cassava brown streak disease in Uganda. Plant Dis 91(1):24-29. doi:10.1094/PD-91-0024

Alves AAC (2002) Cassava botany and physiology. In: Hillocks RJ, Thresh JM, Bellotti AC (eds) Cassava, 
biology, production and utilization. CABI Publishing, Wallingford

Arene OB, Odurukwe SO (1976) Limitations in the use of NPK fertilizer in the control of cassava bacterial blight. In: Terry ER (ed) Cassava bacterial blight in Africa-past, present and future. Workshop report, Centre of Overseas Pest Research, London

Carsky RJ, Toukourou MA (2005) Identification of nutrients limiting cassava yield maintenance on a sedimentary soil in southern Benin, West Africa. Nutr Cycl Agroecosyst 71:151-162. doi:10.1007/s10705-004-1803-9

CIMMYT (1988) From agronomic data to farmer recommendations: An economics training manual. Completely revised edition, CIMMYT, Mexico, DF

Connor DJ, Cock JH, Parra GE (1981) Response of cassava to water shortage. I. Growth and yield. Field Crops Res 4:181-200. doi:10.1016/0378-4290(81)90071-X

De Tafur SM, El-Sharkawy MA, Cadavid LF (1997) Response of cassava (Manihot esculenta Crantz) to water stress and fertilization. Photosynthetica 34:233-239. doi:10.1023/A: 1006892607834

Duque L, Setter T, Ceballos H, Fregene M, Alves A (2008) Evaluation of drought tolerance in contrasting cassava varieties genotypes under field controlled water stressed environment. Paper presented at the first scientific meeting of the Global Cassava Partnership CGP-I, Ghent, 2125 July 2008

El-Sharkawy MA (2004) Cassava biology and physiology. Plant Mol Biol 56:481-501. doi:10.1007/s11103-0052270-7

El-Sharkawy MA (2007) Physiological characteristics of cassava tolerance to prolonged droughts in the tropics: Implications for breeding cultivars adapted to seasonally dry and semi-arid environments. Braz J Plant Physiol 19:83-112

FAO (2008) www.faostat.fao.org. Cited 18 July 2008

Fermont AM, van Asten PJA, Giller KE (2008) Increasing land pressure in East Africa: the changing role of cassava and consequences for sustainability of farming systems. Agric Ecosyst Environ 128:239-250. doi:10.1016/j.agee.2008. 06.009

Howeler RH (1998) Cassava agronomy research in Asia-an overview, 1993-1996. In: Howeler RH (ed) Cassava breeding, agronomy and farmer participatory research in Asia. Proceedings 5th regional workshop, Danzhou, 3-8 Nov 1996

Howeler RH (2002) Cassava mineral nutrition and fertilization. In: Hillocks RJ, Thresh JM, Bellotti AC (eds) Cassava, biology, production and utilization. CABI Publishing, Wallingford

Howeler RH (2008) Results, achievements and impact of the Nippon Foundation Cassava Project. In: Howeler RH (ed) Integrated cassava-based cropping systems in Asia. Proceedings of the Workshop of the Nippon Foundation Cassava project in Thailand, Vietnam and China. Thai Nguyen, 27-31 Oct, 2003

Howeler RH, Cadavid LF (1990) Short and long-term fertility trials in Colombia to determine the nutrient requirements of cassava. Fert Res 26:61-80. doi:10.1007/BF01048744

IITA (1990) Cassava in tropical Africa: a reference manual. Chayce Publication Services, UK, p 196
Jaetzold R, Schmidt H (1982) Farm management handbook of Kenya, vol vol II. Natural Conditions and Farm Management Information. Part A, western Kenya. Kenya Ministry of Agriculture, Nairobi

KARI (2000) Uganda soils map. 1:1.500.000. National Soils Reference Centre, Kawanda Agricultural Research Institute (KARI), Uganda

Kasele IN (1983) Studies on the effects of some environmental factors on cassava (Manihot esculenta Crantz) tuberization. MSc thesis, University of Ibadan/International Institute of Tropical Agriculture, Ibadan

Kelly VA (2006) Factors affecting demand for fertilizers in Sub-Saharan Africa. Agriculture and rural development discussion paper 23. The World Bank, Washington, DC

Kim HS, Hartman GL, Manandhar JB, Graef GL, Steadman JR, Diers BW (2000) Reaction of soybean cultivars to Sclerotinia stem rot in field, greenhouse, and laboratory evaluations. Crop Sci 40:665-669

Legg JP, Owor B, Sseruwagi P, Ndunguru J (2006) Cassava mosaic disease in East and Central Africa: epidemiology and management of a regional pandemic. Adv Virus Res 67:355-418. doi:10.1016/S0065-3527(06)67010-3

Leihner D (2002) Agronomy and cropping systems. In: Hillocks RJ, Thresh JM, Bellotti AC (eds) Cassava, biology, production and utilization. CABI Publishing, Wallingford

Lema KM, Tata-Hangy K, Bidiaka M (2004) Management of African root and tuber scale using improved cassava genotypes and mineral fertilizers. Afr Crop Sci J 12:217-221

Lozano JC, Bellotti A, Reyes JA, Howeler R, Leihner D, Doll J (1981) Field problems in cassava. Centro Internacional de Agricultura Tropical, Cali

Mahli SS, Nyborg M, Solberg ED (1996) Influence of source, method of placement and simulated rainfall on the recovery of ${ }^{15} \mathrm{~N}$-labelled fertilizers under zero tillage. Can J Soil Sci 76:93-100

Mead R (1988) The design of experiments: statistical principles for practical applications. Cambridge University Press, Cambridge

Melifonwu AA (1994) Weeds and their control in cassava. Afr Crop Sci J 2:519-530

Mollard E (1987) African cassava mosaic disease among farmers of the lower Ivory Coast. In: Proceedings of the international seminar: African Cassava Mosaic disease and its control. CTA, FAO, ORSTROM, IITA, IAPC, Yamoussoukro, Côte d'Ivoire, 7-8 May 1987

Nguyen H, Schoenau JJ, Nguyen D, van Rees K, Boehm M (2002) Effects of long-term nitrogen, phosphorus, and potassium fertilization on cassava yield and plant nutrient composition in North Vietnam. J Plant Nutr 25(3):425442. doi:10.1081/PLN-120003374

Nweke FI (1994) Farm level practices relevant to cassava plant protection. Afr Crop Sci J 2:563-582

Obigbesan GO, Matuluka EO (1977) Effect of K and CBB on yield and chemical composition of cassava cultivars. In: Proceedings of the 4th symposium of the International Society for Tropical Root Crops. CIAT, Cali, 1976

Odurukwe SO, Arene OB (1980) Effect of N, P, K fertilizers on cassava bacterial blight and root yield of cassava. Trop Pest Manage 26:391-395

Ofori CS (1973) Decline in fertility status of a tropical forest ochrosol under continuous cropping. Exp Agric 9:15-22 
Ogbe FO, Ohiri AC, Nnodu EC (1993) Effect of NPK fertilization on symptom severity of African cassava mosaic virus. Int J Pest Manage 38:80-83

Okalebo JR, Gathua KW, Woomer PL (2002) Laboratory methods for soil and plant analysis: a working manual. The tropical soil biology and fertility program. Regional Office for Science and Technology for Africa, UNESCO, Nairobi

Pellet D, El-Sharkawy MA (1993) Cassava varietal response to phosphorus fertilization. II Phosphorus uptake and use efficiency. Field Crops Res 35:13-20. doi:10.1016/03784290(93)90132-7

Pellet DM, El-Sharkawy MA (1997) Cassava varietal response to fertilization: growth dynamics and implications for cropping sustainability. Expl Agric 33:353-365

Persley G, Terry ER, Macintyre R (eds) (1976) Concluding statement by participants. Report of an interdisciplinary workshop on cassava bacterial blight. IITA, Ibadan, 1-4 Nov 1976

Richards IR (1979) Response of tropical crops to fertilizer under farmers conditions - analysis of results of the FAO Fertilizer Programme. Phosphorus Agric 76:147-156

Shatar TM, McBratney AB (2004) Boundary-line analysis of field-scale yield response to soil properties. J Agric Sci 142:553-560. doi:10.1017/S0021859604004642

Sseruwagi P, Otim-Nape GW, Osiru DSO, Thresh JM (2003) Influence of NPK fertilizer on populations of the whitefly vector and incidence of cassava mosaic virus disease. Afr Crop Sci J 11(3):171-179

Tittonell P, Vanlauwe B, Corbeels M, Giller KE (2008) Yield gaps, nutrient use efficiencies and responses to fertilizers by maize across heterogeneous smallholder farms in western Kenya. Plant Soil 313:19-37. doi:10.1007/ s11104-008-9676-3

Van Asten PJA, Wopereis MCS, Haefele S, Isselmou MO, Kropff MJ (2003) Explaining yield gaps on farmer-identified degraded and non-degraded soils in a Sahelian irrigated rice scheme. Neth J Agric Sci 50:277-296

Vanlauwe B, Tittonell P, Mukalama J (2006) Within-farm soil fertility gradients affect response of maize to fertilizer application in western Kenya. Nutr Cycl Agroecosyst 76:171-182. doi:10.1007/s10705-005-8314-1

Webb RA (1972) Use of boundary line in analysis of biological data. J Hortic Sci 47:309-319

Zingore S, Murwira HK, Delve RJ, Giller KE (2007) Soil type, historical management and current resource allocation: three dimensions regulating variability of maize yields and nutrient use efficiencies on African smallholder farms. Field Crops Res 101:296-305. doi:10.1016/j.fcr.2006.12.006

Zinsou V, Wydra K, Ahohuendo B, Hau B (2004) Effect of soil amendments, intercropping and planning time in combination on the severity of cassava bacterial blight and yield in two ecozones of West Africa. Plant Pathol 53:585-595. doi:10.1111/j.0032-0862.2004.01056.x 